\title{
A MECHANISTIC APPROACH TO THE ELECTROFORMATION OF ANODIC LAYERS ON COPPER AND THEIR ELECTROREDUCTION IN AQUEOUS SOLUTIONS CONTAINING NaHCO $\mathrm{NAND} \mathrm{Na}_{2} \mathrm{CO}_{3}$
}

\author{
M. Pérez Sánchez, R. M. Souto, M. Barrera, S. González, R. C. Salvarezza* and \\ A. J. ARVIA* \\ Departamento de Química Fisica, Universidad de La Laguna, Tenerife, Spain
}

(Received 18 June 1992; in revised form 9 September 1992)

\begin{abstract}
The electrochemical behaviour of $\mathrm{Cu}$ in solutions containing $\mathrm{Na}_{2} \mathrm{CO}_{3}+\mathrm{NaHCO}_{3}$ $(8.8<\mathrm{pH}<11.1)$ has been studied using potentiodynamic and potentiostatic techniques complemented by Scanning Electron Microscopy. The initial stages of the anodic layer formation involve the electroformation of a thin inner $\mathrm{Cu}_{2} \mathrm{O}$ layer followed by the growth of a $\mathrm{CuO} / \mathrm{Cu}(\mathrm{OH})_{2}-\mathrm{CuCO}_{3}$ complex outer layer. Soluble $\mathrm{Cu}$ (II) species were detected in the entire anodization potential range. Kinetic models devised for phase change electrochemical processes have been applied to explain the characteristics of anodic and cathodic current transients.
\end{abstract}

Key words: $\mathrm{Cu}$ corrosion, $\mathrm{Cu}$ anodic layers, nucleation and growth processes, solution composition, $\mathrm{Cu}$ passivation.

\section{INTRODUCTION}

The electrochemical behaviour of $\mathrm{Cu}$ in moderate alkaline media has been widely studied both in plain $\mathrm{NaOH}$ and in salt-containing solutions at different $\mathrm{pH}[1-10] . \mathrm{Cu}$ passivation in plain $\mathrm{NaOH}$ solutions was described through two main processes, namely, the initial formation of the $\mathrm{Cu}_{2} \mathrm{O}$ monolayer followed by the growth of a massive $\mathrm{Cu}_{2} \mathrm{O}$ layer, and the build-up of the $\mathrm{CuO}-\mathrm{Cu}(\mathrm{OH})_{2}$ layer, the overall process being accompanied by the formation of $\mathrm{Cu}(\mathrm{I})$ and $\mathrm{Cu}$ (II) soluble species[7-9]. Accordingly, the anodic layer consisted of a complex layer involving initial reactions leading to a $\mathrm{Cu} / \mathrm{Cu}_{2} \mathrm{O}$ (porous inner layer) structure and further growth of a $\mathrm{Cu} / \mathrm{Cu}_{2} \mathrm{O}$ (porous inner layer) $/ \mathrm{CuO} / \mathrm{Cu}(\mathrm{OH})_{2}$ structure was advanced $[7,8]$. It was also found that the relative contribution of the two main processes and the structure of the passive layer depended on a number of variables, such as the potential routine employed in the experiments, the solution composition, the $\mathrm{Cu}$ surface treatment and the temperature $[7-9,11-13]$.

The protective properties of the anodic layer produced on $\mathrm{Cu}$ in alkaline solutions vary strongly with the nature of anions in the solution[13-15]. Thus, in aqueous solutions containing either a carbonate[13] or a phosphate salt[15] the protective properties of the anodic layer could be improved, although this effect depends considerably on the $\mathrm{pH}$, the relative concentration of anions in the solution and the solubility product of the corresponding $\mathrm{Cu}$ salts. Occasionally, as occurs in alkaline solutions containing either carbonate[13] or phosphate salts[15],

- Visiting Professor, INIFTA, Universidad Nacional de La Plata, La Plata, Argentina. insoluble $\mathrm{Cu}$ salts become a part of the anodic layer. Conversely, the high solubility of $\mathrm{Cu}$ salts could favour a more extensive attack of $\mathrm{Cu}$ eventually leading to pitting corrosion $[8,13,16-20]$. Nevertheless, whether the anodic layer produced on $\mathrm{Cu}$ behaves as either a protective or a non-protective layer depends not only on its chemical composition but also on its compactness and adhesion to the $\mathrm{Cu}$ substrate. These two properties are closely related to the kinetics and mechanism of the growth of new phases entering the anodic layer formation $[7,8]$.

Voltammetric data of $\mathrm{Cu}$ in moderate alkaline solutions $[13,20]$ suggest that the main characteristics of the passivating layer could be accounted for through a composed-type passivating layer structure as that already referred to above. However, for the anodization of $\mathrm{Cu}$ in $\mathrm{NaHCO}_{3}$ and $\mathrm{Na}_{2} \mathrm{CO}_{3}$ aqueous solutions, SEM and Electron Microprobe Analysis data indicated that $\mathrm{Cu}$ carbonates participate in the formation of the anodic layer structure from the very beginning of the reaction in different ways depending on the $\mathrm{HCO}_{3}^{-}$ion concentration. Thus, at high positive potentials and low $\mathrm{HCO}_{3}^{-}$ion concentrations $\mathrm{Cu}$ pitting could be promoted $[13$, 20]. However, the precipitation of $\mathrm{Cu}$ (II) carbonates in the pits hindered pit stabilization and growth [13, 20]. Otherwise, in solutions containing $\mathrm{Cl}^{-}$ions the $\mathrm{HCO}_{3}^{-}$ion acted as a pitting inhibitor shifting the breakdown potentials obtained in solutions containing the $\mathrm{Cl}^{-}$ion to more positive potentials[20].

The following aspects of the electrochemistry of $\mathrm{Cu}$ in $\mathrm{NaHCO}_{3}+\mathrm{Na}_{2} \mathrm{CO}_{3}$ aqueous solutions at different $\mathrm{pH}(8.8<\mathrm{pH}<11.1)$ are reported in this work: (i) the identification of the anodic and cathodic processes; (ii) the influence of stirring on $\mathrm{Cu}$ corrosion and passivation in those media; (iii) the participation of $\mathrm{CO}_{3}^{2-}$ and $\mathrm{HCO}_{3}^{-}$ions in the formation of soluble Cu(II) species; (iv) the probable 
mechanisms related to the formation and to the disappearance of solid phases related to $\mathrm{Cu}$ corrosion and passivation; and ( $v$ ) the comparative behaviour of $\mathrm{Cu}$ in different aqueous electrolytes.

\section{EXPERIMENTAL}

A conventional three-electrode electrochemical cell was used. Working electrodes consisted of flat $\mathrm{Cu}$ discs $(0.3 \mathrm{~cm}$ dia.) prepared from electrolytic $\mathrm{Cu}$ rods. Two types of specimens (i) and (ii), were used as working electrodes: (i) mechanically mirror-polished $\mathrm{Cu}$ specimens with fine-grained (silicon carbide) emery papers ranging from 30 to $5 \mu \mathrm{m}$ grit, rinsed with distilled water, and finally dried in air; (ii) thermally treated $\mathrm{Cu}$ specimens annealed at $500^{\circ} \mathrm{C}$ for $2 \mathrm{~h}$ under a few $\mathrm{mm}$ pressure Ar gas to eliminate residual mechanical stresses[15]. These specimens were electropolished in aqueous $85 \% \quad \mathrm{H}_{3} \mathrm{PO}_{4}$ at $0.3 \mathrm{~A} \mathrm{~cm}^{-2}$ for $5-10 \mathrm{~min}$ at room temperature, then rinsed thoroughly with distilled water, and finally dried under Ar. Thermally treated and electropolished $\mathrm{Cu}$ specimens provided the most reproducible electrochemical data.

Each $\mathrm{Cu}$ specimen was axially mounted at the extreme of the shaft of a rotating disc electrode device so that the contact between the $\mathrm{Cu}$ disc surface and the solution was made through a hanging meniscus-disc-electrode arrangement[21, $22]$. The potential of the working electrode was measured against a $\mathrm{NaCl}$ (saturated)-calomel electrode (ssce). A cylindrical Pt grid was used as counter electrode.

Solutions were prepared from twice-distilled water and A.R. chemicals, and purged with Ar. The entire electrochemical system was run continuously under Ar. The following solutions were employed in the present work, $(0.1-x) \mathrm{M} \mathrm{NaHCO}+x \mathrm{M} \mathrm{Na}_{2} \mathrm{CO}_{3}$ for $x=0, \quad 0.01, \quad 0.03,0.05, \quad 0.07$ and 0.1 $(8.8<\mathrm{pH}<11.1)$. To establish possible specific effects of anions, experiments in $0.075 \mathrm{M} \mathrm{Na} \mathrm{Na}_{4} \mathrm{O}_{7}$ $+0.15 \mathrm{M} \mathrm{H}_{3} \mathrm{BO}_{3}$ buffer $(\mathrm{pH}=9.0$ ) and in $0.075 \mathrm{M}$ $\mathrm{Na}_{2} \mathrm{~B}_{4} \mathrm{O}_{7}+0.15 \mathrm{M} \quad \mathrm{H}_{3} \mathrm{BO}_{3}+y \mathrm{M} \quad \mathrm{NaHCO}_{3}$ $(y=0.01$ and 0.1$)$ were also performed.

A new Cu specimen was used for each run. Firstly, the working electrode was potential cycled at $0.01 \mathrm{~V} \mathrm{~s}^{-1}$ from $E_{\mathrm{sc}}=-0.80 \mathrm{~V}$ to $0.35 \leqslant E_{\mathrm{sa}} \leqslant$ $0.80 \mathrm{~V}$, depending of the solution composition. Conventional single sweep and repetitive voltammograms, current/potential curves under working electrode rotation, and potentiostatic current transients under different conditions were recorded using conventional circuitries. All runs were performed at $25 \pm 0.1^{\circ} \mathrm{C}$.

\section{RESULTS AND INTERPRETATION}

\subsection{Voltammetric data}

3.1.1. General features. Cyclovoltammograms were run with $\mathrm{Cu}$ specimens of both types: (i) and (ii) at various $\mathrm{pH}$, potential sweep rates $(v)$ and anodic $\left(E_{\mathrm{sa}}\right)$ and cathodic $\left(E_{\mathrm{sc}}\right)$ switching potentials to establish the potential ranges of the different electrochemical reactions of $\mathrm{Cu}$ in the working solutions and their kinetic characteristics, and to select the most adequate conditions for the potentiostatic investigation of either the electroformation of corrosion and passivating products or their electroreduction reactions. The voltammograms became highly dependent on $\mathrm{pH}$, solution composition, $E_{\mathrm{sa}}$, $E_{\mathrm{sc}}$ and duration of the potential cycling.

The cyclovoltammograms of $\mathrm{Cu}$ in $0.1 \mathrm{M}$ $\mathrm{NaHCO}_{3}$ (pH 8.8) and in $0.05 \mathrm{M} \mathrm{NaHCO}_{3}+0.05 \mathrm{M}$ $\mathrm{Na}_{2} \mathrm{CO}_{3}$ (pH 9.8) (Fig. 1) are qualitatively comparable. During the potential cycling the voltammetric charges relating to peaks $\mathrm{II}_{\mathrm{a}}, \mathrm{I}_{\mathrm{c}}$ and $\mathrm{II}_{\mathrm{c}}$ become particularly enhanced. Trends in the change of the different peaks are indicated by the arrows in Fig. 1. After a certain number of cyles, which depends on solution $\mathrm{pH}$ and switching potentials, the stabilized voltammograms are attained for all solutions used in this work (Fig. 2). These voltammograms show a cathodic current baseline related to the electrodeposition of soluble $\mathrm{Cu}$ (II) which has been formed during the repetitive scans. The magnitude of this current depends on both the applied potential routine and the $\mathrm{Cu}$ electrode pretreatment.

Peaks $I_{a}$ and $\mathrm{II}_{\mathrm{a}}$ are related to the formation of $\mathrm{Cu}_{2} \mathrm{O}$ and $\mathrm{CuO}$, respectively, as in plain $\mathrm{NaOH}$ solutions[11]. When $E_{\mathrm{sa}}$ is set above $0.0 \mathrm{~V}$ an anodic
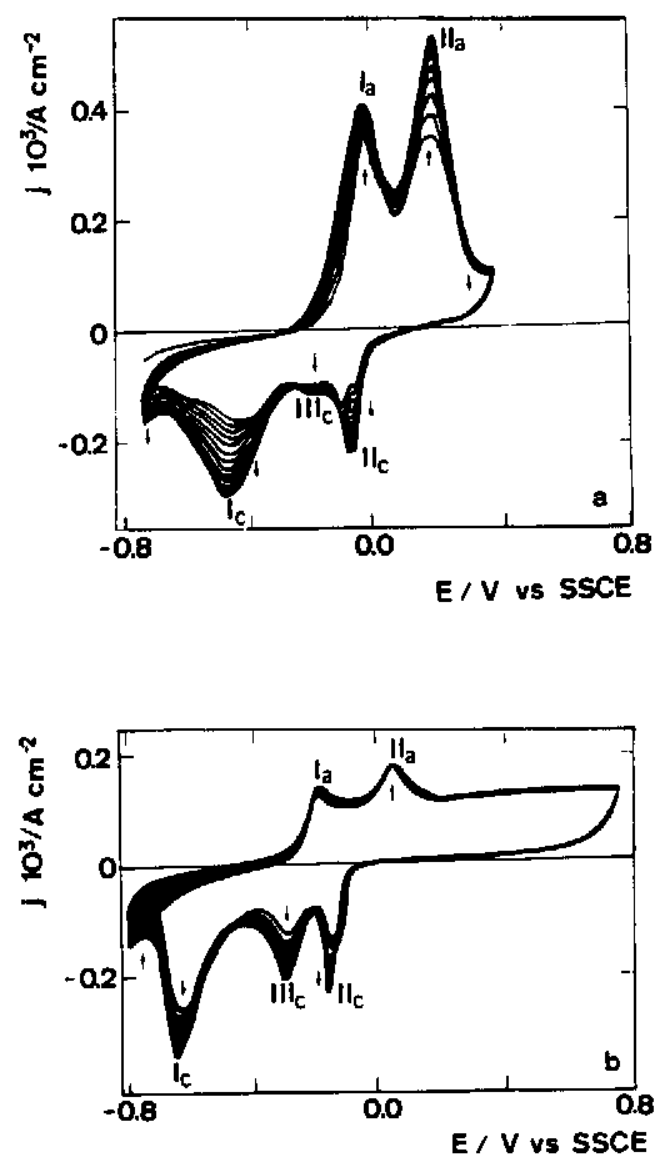

Fig. 1. Cyclovoltammograms resulting for $\mathrm{Cu}$ specimens (type i) at $0.01 \mathrm{~V} \mathrm{~s}^{-1}$ : (a) $0.1 \mathrm{M} \mathrm{NaHCO} 3, \mathrm{pH} \mathrm{8.8;} \mathrm{(b)}$

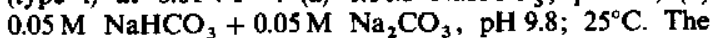
arrows indicate the trend of the voltammograms to reach the stabilized current-potential profiles. 

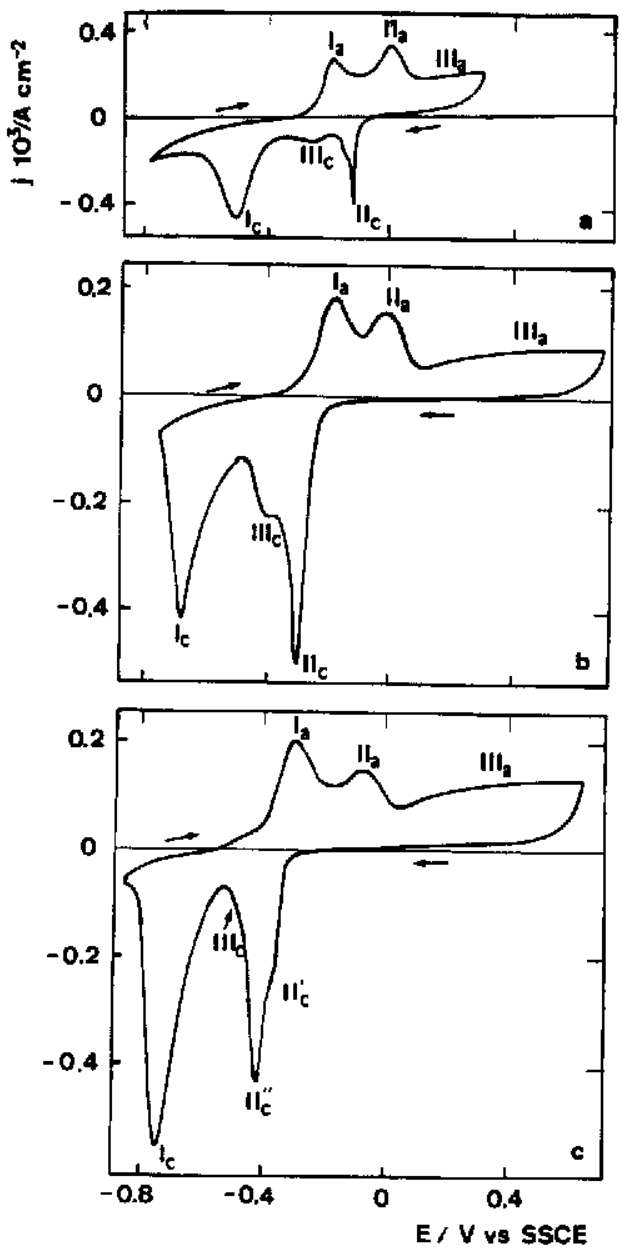

Fig. 2. Voltammograms run with $\mathrm{Cu}$ specimens (type i) at $0.01 \mathrm{~V} \mathrm{~s}^{-1}$; (a) $0.1 \mathrm{M} \mathrm{NaHCO}{ }_{3}, \mathrm{pH} 8.8 ;$ (b) $0.07 \mathrm{M}$ $\mathrm{NaHCO}_{3}+0.03 \mathrm{M} \mathrm{Na}_{2} \mathrm{CO}_{3}, \mathrm{pH} 9.8$; (c) $0.1 \mathrm{M} \mathrm{Na} \mathrm{CO}_{3}$, pH 11.1. $25^{\circ} \mathrm{C}$.

current plateau (III,) extending up to $0.40 \mathrm{~V}$ can be observed. The reverse potential scan shows three cathodic peaks $\left(\mathrm{I}_{c}, \mathrm{II}_{\mathrm{c}}\right.$ and $\left.\mathrm{III}_{c}\right)$ instead of two peaks found in plain $\mathrm{NaOH}$ solutions. Peak $\mathrm{II}_{\mathrm{c}}$ is a complex peak involving the contributions of peaks $\mathrm{II}_{\mathrm{c}}^{\prime}$ and $\mathrm{II}_{\mathrm{c}}^{\prime \prime}$, the relative height of these peaks changing with both potential cycling time and $E_{x s}$. The appearance of peak III $_{c}$ is enhanced as $E_{\mathrm{sa}}$ is set in the current plateau (III) region. Peak III $_{c}$ has been assigned to the electroreduction of the $\mathrm{Cu}$ carbonate- $\mathrm{Cu}$ hydroxide layer formed at potentials more positive than $0.0 \mathrm{~V}[13]$, whereas peaks $\mathrm{II}_{\mathrm{c}}$ and $I_{c}$ have been associated with the electroreduction of $\mathrm{CuO}-\mathrm{Cu}(\mathrm{OH})_{2}$ to $\mathrm{Cu}_{2} \mathrm{O}$, and $\mathrm{Cu}_{2} \mathrm{O}$ to $\mathrm{Cu}$, respectively.

The potentials of the anodic ( $\mathrm{I}_{2}$ and $\left.\mathrm{II}_{2}\right)$ and the cathodic $\left(I_{c}\right.$ and $\left.I_{c}\right)$ peaks shift linearly with $\mathrm{pH}$. These dependences are given through the follow-

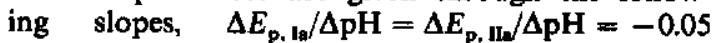
$\pm 0.01 \mathrm{~V} / \mathrm{pH}$ unit, and $\Delta E_{\mathrm{p}, \mathrm{re}}^{\mathrm{p}} / \Delta \mathrm{pH}=\Delta E_{\mathrm{p}, \mathrm{IId}}$ $\Delta \mathrm{pH}=-0.120 \pm 0.015 \mathrm{~V} / \mathrm{pH}$ unit, where $E_{\mathrm{p}, 1}$ stands for the potential of current peak $i\left(i=I_{a}, I_{c}, I I_{a}, I I_{c}\right)$. The $\mathrm{pH}$ dependences of $E_{\mathrm{p}, \text { in }}$ and $E_{\mathrm{p}, \text { In }}$ approach the predictions of Nernst equations for $\mathrm{Cu} / \mathrm{Cu}_{2} \mathrm{O}$ and $\mathrm{Cu}_{2} \mathrm{O} / \mathrm{CuO}$ reactions at equilibrium, respectively[2]. For peak III $_{\mathrm{c}}$ no clear-cut $\mathrm{pH}$ dependence could be determined. The shift of peaks $I_{c}$ and $I_{c}$ with $p H$ makes peak III $_{\mathrm{c}}$ appear as a separate peak located between peaks $\mathrm{II}_{\mathrm{c}}$ and $\mathrm{I}_{\mathrm{c}}$ at the lowest $\mathrm{pH}$ (Fig. 2a).

At constant $\mathrm{pH}$, the single sweep voltammograms for a $\mathrm{Cu}$ specimen (type ii) in $0.1 \mathrm{M} \mathrm{NaHCO}{ }_{3}$, pH 8.8, run by changing $E_{s}$ stepwise positively, show the following features: (i) both peaks $I_{c}$ and $I_{c}$ move negatively as expected for a progressive contribution of ageing processes at the anodically-formed product layer[23]; (ii) peak III $_{c}$ can be detected when $E_{\mathrm{se}}$ exceeds the potential range of peak $\mathrm{II}_{\mathbf{2}}$; (iii) peaks II and $\mathrm{I}_{\mathrm{a}}$ are largely overlapped; (iv) the single sweep voltammetric condition and $E_{s s}<0.40 \mathrm{~V}$ makes the cathodic current baseline appear extremely small. Furthermore, the rotation of the $\mathrm{Cu}$ specimens results in the increase of the anodic current recorded from $-0.20 \mathrm{~V}$ upwards, the decrease of the cathodic to anodic voltammetric charge ratio, and the positive shift of $E_{\mathrm{p}, \mathrm{Ic}}$ and $E_{\mathrm{p}, \mathrm{Ul}}[13]$.

A series of voltammograms were run with $\mathrm{Cu}$ specimens (type ii) starting the first positive going potential scan in still solution, and commencing the working electrode rotation at $\omega=1000 \mathrm{rpm}$ during the reverse scan from $0.20 \mathrm{~V}$ downwards (Fig. 3). In these cases, stirring at point $\mathrm{A}$ produces a sudden anodic current jump attaining a plateau which covers the $0.20-0.0 \mathrm{~V}$ range. Below $0.0 \mathrm{~V}$ the anodic current decreases and later at $-0.18 \mathrm{~V}$ changes over to a cathodic current. The negative going potential scan shows a considerable decrease in the height of peak $I_{c}$, and the absence of peaks $\mathrm{II}_{c}$ and $\mathrm{III}_{\mathrm{c}}$. The second cyclovoltammogram run from $-0.80 \mathrm{~V}$ upwards displays an anodic current plateau covering the potential range of peak $I_{a}$, and partially that of peak II . Furthermore, a near linear anodic current

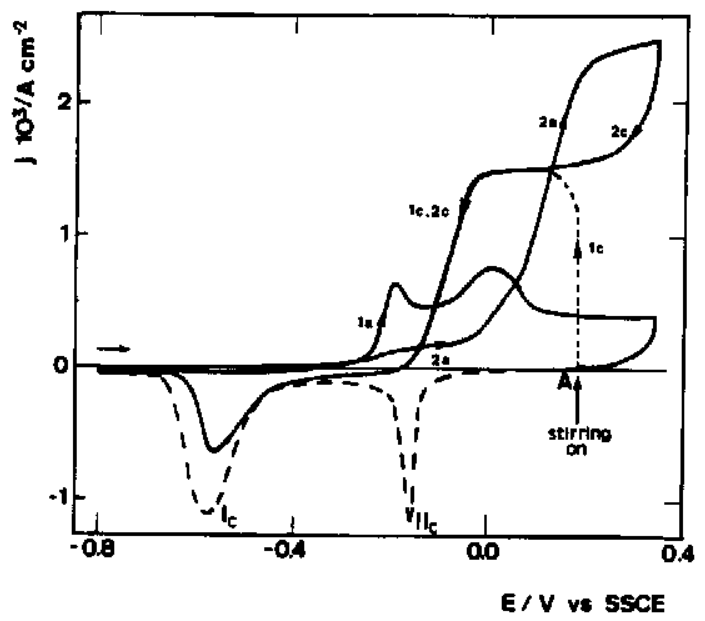

Fig. 3. Cyclovoltammograms run for $\mathrm{Cu}$ specimens (type ii); $0.1 \mathrm{M} \mathrm{NaHCO} ; 25^{\circ} \mathrm{C}$. The voltammetric sweep commences at $-0.8 \mathrm{~V}$. The sequence of the sweeps is: 1a (quiescent solution); 1c; 2a; and 2c (under stirring at $1000 \mathrm{rpm}$ ). Stirring was started when the potential sweep reached point $A$. The dashed line corresponds to the cathodic profile in the absence of stirring. 

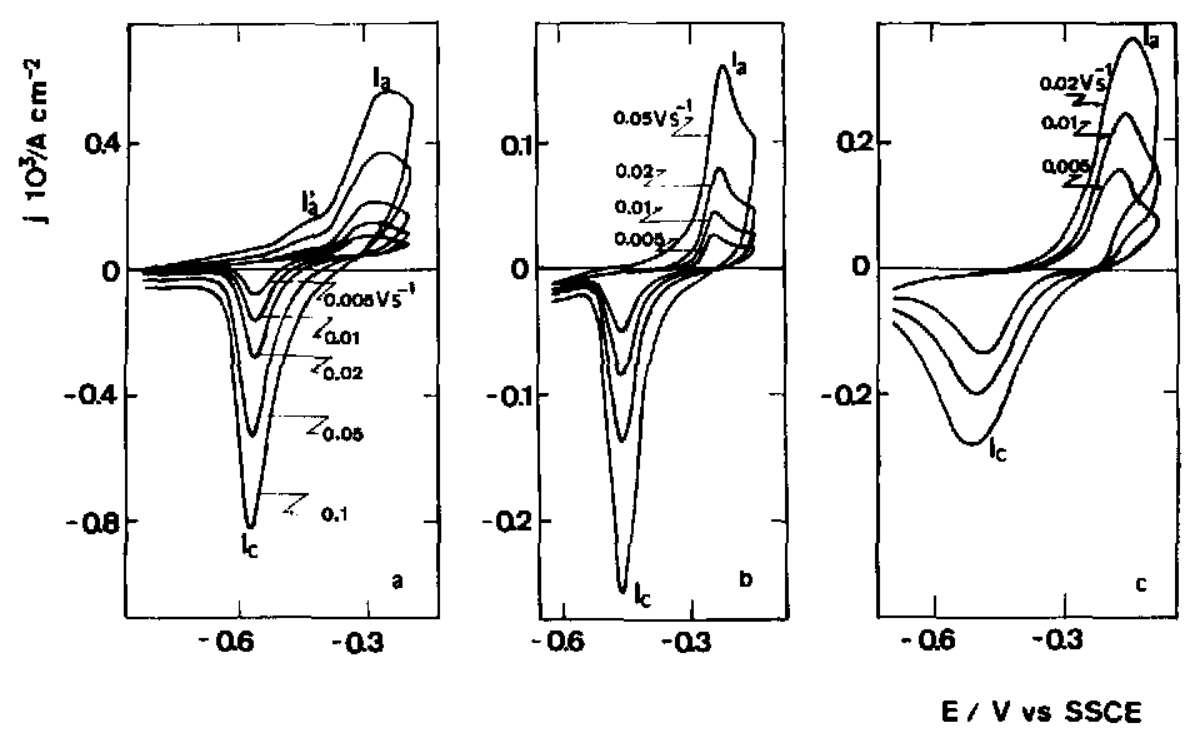

Fig. 4. Stabilized voltammograms resulting for $\mathrm{Cu}$ specimens (type i) in the potential region of $\mathrm{Cu}(\mathrm{O}) /$ $\mathrm{Cu}(\mathrm{I})$ redox system at different $v$ values as indicated in the figures: (a) $0.1 \mathrm{M} \mathrm{Na}_{2} \mathrm{CO}_{3}, \mathrm{pH} 11.1$; (b) $0.05 \mathrm{M}$ $\mathrm{NaHCO}_{3}+0.05 \mathrm{M} \mathrm{Na}_{2} \mathrm{CO}_{3}$, pH 9.8; (c) $0.1 \mathrm{M} \mathrm{NaHCO}_{3}, \mathrm{pH} 8.8 ; 25^{\circ} \mathrm{C}$.

increase in the -0.02 to $0.06 \mathrm{~V}$ range followed by a steep increase up to a current plateau covering from ca. $0.25 \mathrm{~V}$ to $E_{\mathrm{sa}}$ can be observed. The subsequent reverse voltammogram shows a current loop with a crossing potential at $c a$. $0.12 \mathrm{~V}$, and afterwards the voltammogram tends to coincide with the previous one.

According to the preceding results stirring promotes $\mathrm{Cu}$ corrosion in the $\mathrm{Na}_{2} \mathrm{CO}_{3}-\mathrm{NaHCO}_{3}$ solution probably because the formation of the outer part of the anodic layer is largely impeded. As seen through peak $I_{c}$, apparently a part of the inner anodic layer, ie the $\mathrm{Cu}_{2} \mathrm{O}$ layer remains on the $\mathrm{Cu}$ substrate even under stirring.

3.1.2. Conjugated redox couples. Voltammograms run by adequately setting $E_{\mathrm{sa}}$ and $E_{\mathrm{sc}}$ allow to identify the conjugated pair of peaks related to the $\mathrm{Cu} / \mathrm{Cu}_{2} \mathrm{O}$ (Fig. 4) and the $\mathrm{Cu}_{2} \mathrm{O} / \mathrm{CuO}$ (Fig. 5) redox reactions at different $\mathrm{pH}$.

The electro-oxidation of $\mathrm{Cu}$ to $\mathrm{Cu}(\mathrm{I})$ in $0.1 \mathrm{M}$ $\mathrm{Na}_{2} \mathrm{CO}_{3}$ (Fig. 4a) implies the initial formation of a $\mathrm{Cu}(\mathrm{OH})_{\text {ad }}$ precursor (hump $\left.\mathrm{I}_{\mathrm{a}}^{\prime}\right)$ at a potential slightly
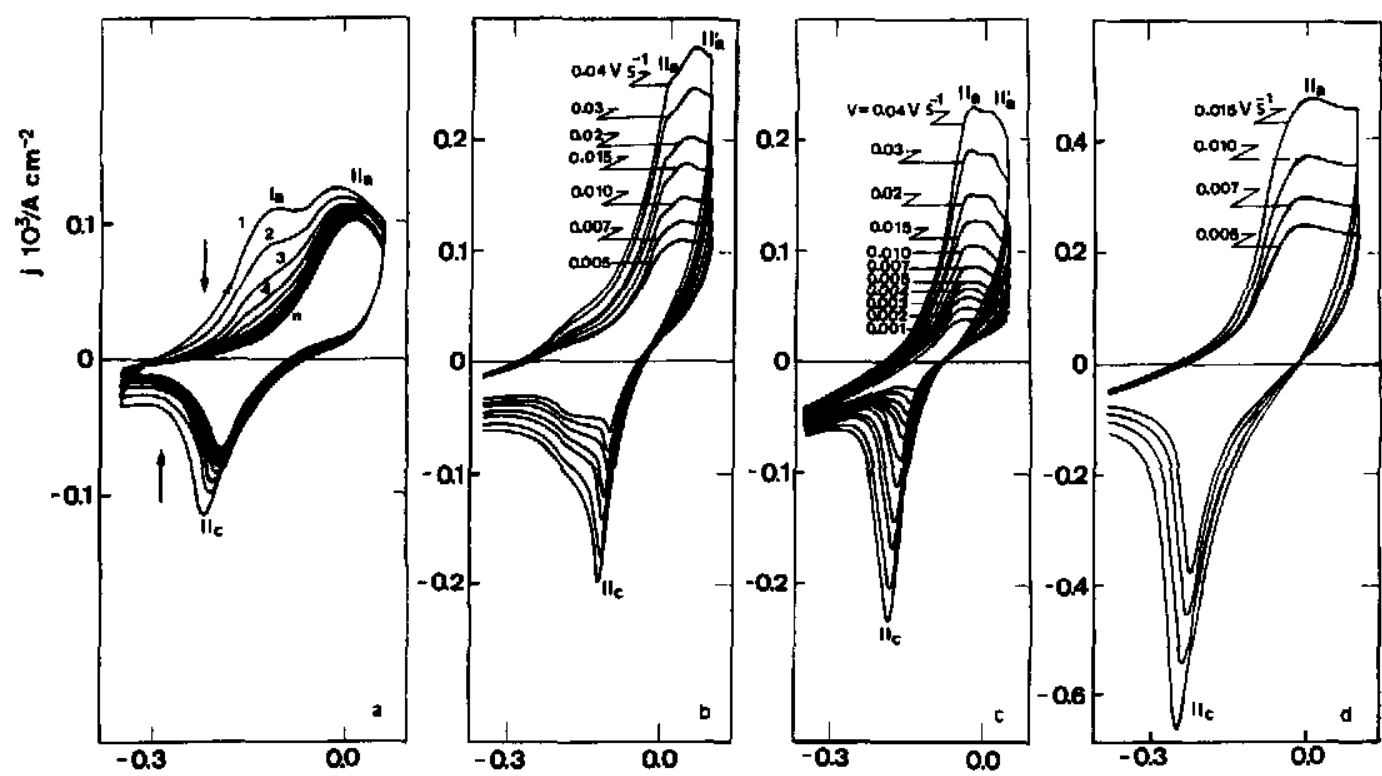

E/V vs SSCE

Fig. 5. (a) Stabilization of the voltammograms obtained on $\mathrm{Cu}$ specimens (type ii) at $0.01 \mathrm{Vs}^{-1}$ in the potential range of peaks II, and $\mathrm{II}_{\mathrm{c}}$ in $0.1 \mathrm{M} \mathrm{NaHCO}, \mathrm{pH} 8.8$. (b)-(d) Stabilized voltammograms resulting in the potential region of $\mathrm{Cu}(\mathrm{I}) / \mathrm{Cu}(\mathrm{II})$ redox system at different $v$ values in (b) $0.1 \mathrm{M} \mathrm{NaHCO}$,

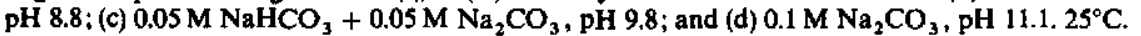


lower than the reversible potential of the $\mathrm{Cu}(\mathrm{O}) /$ $\mathrm{Cu}(\mathrm{I})$ system, followed by the appearance of $\mathrm{Cu}_{2} \mathrm{O}$ when the potential of hump $\mathrm{I}_{\mathrm{a}}^{\prime}$ is exceeded[11]. Comparable results are obtained for the $0.5 \mathrm{M} \mathrm{Na} \mathrm{CO}_{3}$ $+0.5 \mathrm{M} \mathrm{NaHCO}_{3}$ (Fig. 4b) and $0.1 \mathrm{M} \mathrm{NaHCO}$ (Fig. 4c) solution, although in these cases hump $I_{2}^{\prime}$ appears poorly defined.

Parametric relationships for $j_{p, j}$ and $E_{p, j}$ could be established at different values of $v$, where $j_{\mathrm{p}, \mathrm{i}}$ stands for the apparent peak current density values for $i=$ $I_{a}, I_{c}, I I_{\text {a }}$ and $\mathrm{II}_{c}$. For $0.05 \mathrm{M} \mathrm{NaHCO}_{3}+0.05 \mathrm{M}$ $\mathrm{Na}_{2} \mathrm{CO}_{3}$, a linear $\ln j_{\mathrm{p}, \text { in }}$ vs. In $v$ plot with a slope equal to $0.8 \pm 0.03$ was found. Similar plots were obtained for peak $I_{c}$ although in this case the slope changes from $0.5 \pm 0.03$ for $0.1 \mathrm{M} \mathrm{Na} \mathrm{Na}_{2}$ to $0.8 \pm 0.03$ for $0.1 \mathrm{M} \mathrm{NaHCO}$. The dependence of $E_{\mathrm{p}, \text { In }}$ on $v$ changes with the solution composition. Thus, in either $0.1 \mathrm{M} \mathrm{Na}{ }_{2} \mathrm{CO}_{3}(\mathrm{pH} 11.1)$ or $0.1 \mathrm{M}$ $\mathrm{NaHCO}_{3}$ (pH 8.8) no definite dependence $E_{\mathrm{p}, \text { la }}$ on $v$ could be established due to the somewhat poor quantitative reproducibility of the $\mathrm{Cu}(\mathrm{O}) / \mathrm{Cu}(\mathrm{I})$ reaction. Otherwise, in $0.05 \mathrm{M} \mathrm{NaHCO}{ }_{3}+0.05 \mathrm{M}$ $\mathrm{Na}_{2} \mathrm{CO}_{3}(\mathrm{pH} 9.8)$, a linear decrease of $E_{\mathrm{p} \text {. a }}$ with $\ln v$ is approached with a slope close to $0.01 \mathrm{~V}$ decade ${ }^{-1}$; whereas $E_{\mathrm{p}, \mathrm{Ic}}$ behaves practically independent of $v$ in the $5 \times 10^{-3} \leqslant v \leqslant 0.1 \mathrm{Vs}^{-1}$ range. These parametric relationships, however, become influenced by the local change of $\mathrm{pH}$ and the ageing processes at the anodic layer itself $[23,24]$.

For further investigating the conjugated pair of peaks related to the $\mathrm{Cu}$ (I)/Cu(II) reactions, a potential cycling was first performed until the contribution of peak $I_{a}$ in the voltammogram was practically cancelled (Fig. 5a), and later, the values of $E_{\text {sc }}$ and $E_{\mathrm{s}}$ were set to cover the potential range of the $\mathrm{Cu}(\mathrm{I})$ / $\mathrm{Cu}$ (II) reaction. The stabilized voltammograms run at different $v$ and $\mathrm{pH}$ values (Fig. $5 \mathrm{~b}-\mathrm{d}$ ) show that the electro-oxidation of $\mathrm{Cu}_{2} \mathrm{O}$ to $\mathrm{CuO} / \mathrm{Cu}(\mathrm{OH})_{2}$ in these solutions becomes also a complex process comprising of two largely overlapping peaks. Peak $\mathrm{II}^{\prime}$ is not observed at the highest $\mathrm{pH}$, but it is clearly displayed in $0.1 \mathrm{M} \mathrm{NaHCO}$ (pH 8.8) (Fig. 5b). The dependence of peak $\mathrm{II}_{\mathrm{a}}^{\prime}$ on $v$ becomes greater than that observed for peak $\mathrm{II}_{\mathrm{q}}$. Thus, as $v$ is increased from 0.001 to $2 \mathrm{~V} \mathrm{~s}^{-1}$ the $\mathrm{II}_{\mathrm{a}}^{\prime} / \mathrm{II}_{\mathrm{a}}$ peak height ratio increases with $v$, the greater this increase, the lower the solution $\mathrm{pH}$. At the lowest $\mathrm{pH}$ and $v=0.50 \mathrm{Vs}^{-1}$ both peaks are approximately equal; at $v=2.00 \mathrm{~V} \mathrm{~s}^{-1}$, peak $\mathrm{II}_{\mathrm{a}}^{\prime}$ is higher than peak $\mathrm{II}_{\mathrm{a}}$, and finally, at $v>2 \mathrm{Vs}^{-1}$ both peaks are no longer observed.

A linear $\ln j_{\mathrm{p}}$, la vs. $\ln v$ plot with a slope $c a$. $0.63 \pm 0.03$ for $0.1 \mathrm{M} \mathrm{Na} \mathrm{CO}_{3}$ (pH 11.1) was obtained; whereas two linear portions could be distinguished in both $0.1 \mathrm{M} \mathrm{NaHCO}$ (pH 8.4) and in $0.05 \mathrm{M} \mathrm{NaHCO}{ }_{3}+0.05 \mathrm{M} \mathrm{Na}_{2} \mathrm{CO}_{3}$ (pH 9.8), the corresponding slopes being $0.50 \pm 0.02$ $\left(10^{-3} \leqslant v \leqslant 10^{-2} \mathrm{Vs}^{-1}\right.$ range), and $0.60 \pm 0.03$ $\left(0.02 \leqslant v<0.1 \mathrm{~V} \mathrm{~s}^{-1}\right.$ range). On the other hand, for all solutions two linear portions in the $\ln j_{\mathrm{p} \text {. Ic }}$ vs. $v$ plots were displayed, the corresponding slopes being $0.42 \pm 0.03 \quad\left(0.02 \leqslant v \leqslant 0.1 \mathrm{Vs}^{-1} \quad\right.$ range), and $0.60 \pm 0.03\left(10^{-3} \leqslant v \leqslant 7 \times 10^{-3} \mathrm{~V} \mathrm{~s}^{-1}\right.$ range) for $0.1 \mathrm{M} \mathrm{Na} \mathrm{CO}_{3}$ and $0.05 \mathrm{M} \mathrm{NaHCO}+0.05 \mathrm{M}$ $\mathrm{Na}_{2} \mathrm{CO}_{3}$; and $0.58 \pm 0.03$ and $0.85 \pm 0.03$ for $0.1 \mathrm{M}$ $\mathrm{NaHCO}_{3}$. Besides, a linear $E_{\mathrm{p}}$, Ihe vs. In $v$ plot with a slope close to $R T / 2 F$ is only seen for $0.1 \mathrm{M}$ $\mathrm{Na}_{2} \mathrm{CO}_{3}$. The plot $E_{\mathrm{p} \text {. II }}$ vs. In $v$ behaves similarly to that described for peak $\mathrm{II}_{\mathbf{a}}$.

3.1.3. The influence of $\mathrm{NaHCO}_{3}$ addition on the behaviour of $\mathrm{Cu}$ in borate buffer. The voltammograms of $\mathrm{Cu}$ specimens (type ii) in a borate buffer run at $0.01 \mathrm{Vs}^{-1}$ covering the -0.80 to $0.80 \mathrm{~V}$ range (Fig. 6) show a broad anodic peak containing peaks $\mathrm{I}_{\mathrm{a}}$ and $\mathrm{II}_{\mathrm{a}}$ followed by another broad peak III, [8]. The reverse scan exhibits peak $I_{c}$ and $I_{c}$. In this case the electrode rotation up to $\omega=1000 \mathrm{rpm}$ has no significant influence on the voltammogram.

Similar voltammograms run in borate buffer $+0.01 \mathrm{M} \mathrm{NaHCO}$ for $\omega \leqslant 500 \mathrm{rpm}$ show that both the base anodic and cathodic currents increase with $\omega$ (Fig. 6b). In these voltammograms a distinction among peaks $\mathrm{I}_{2}, \mathrm{II}_{2}$ and $\mathrm{III}_{\mathrm{a}}$ can also be made although peak $I_{a}$ largely overlaps peak $I_{a}$. The reverse scan exhibits an anodic current down to ca. $-0.08 \mathrm{~V}$, ie about $0.17 \mathrm{~V}$ more negative than the reversible potential of $\mathrm{Cu}(\mathrm{II}) / \mathrm{Cu}(\mathrm{O})$ redox couple. In contrast to the overall cathodic charge, under rotation up to about $\omega=500 \mathrm{rpm}$, the overall anodic charge is considerably increased. At $\omega>500 \mathrm{rpm}$ the

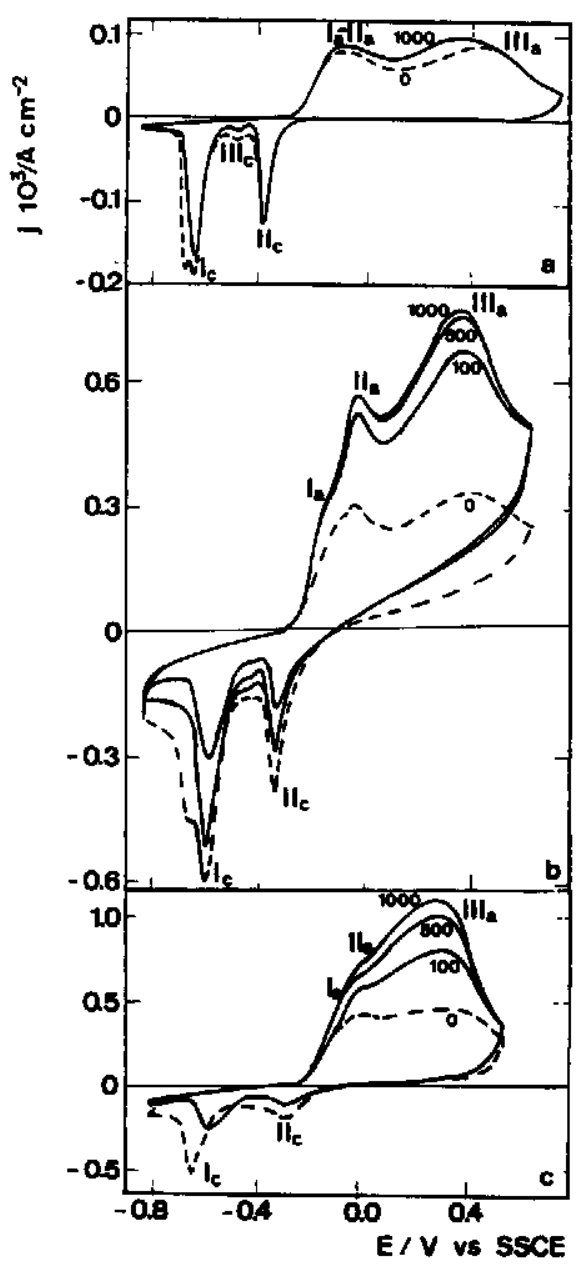

Fig. 6. Stabilized voltammograms run for $\mathrm{Cu}$ specimens (type ii) at $0.01 \mathrm{~V} \mathrm{~s}^{-1}$, measured at different rotation speeds in rpm; $25^{\circ} \mathrm{C}$ : (a) borate buffer; (b) borate buffer $+0.01 \mathrm{M}$ $\mathrm{NaHCO}_{3} ;$ (c) borate buffer $+0.1 \mathrm{M} \mathrm{NaHCO}_{3}$. 
influence of rotation on the electrochemical process tends to disappear. But in all cases, in the negative going potential scan, the crossover potential related to the anodic to cathodic current change remains the same, ie $-0.08 \mathrm{~V}$.

The influence of stirring on the voltammograms can be enhanced by increasing the $\mathrm{NaHCO}_{3}$ concentration in the borate buffer (Fig. 6c). In this case a situation can be reached for which the heights of peaks $I_{c}$ and $\mathrm{II}_{\mathrm{c}}$ become independent of $\omega$, the corresponding peak potentials being positively shifted.

When the voltammogram is initiated from $E_{\mathrm{sc}}$ upwards with a quiescent solution, and as the value of $E_{\mathrm{sa}}$ is reached, stirring at $\omega=1000 \mathrm{rpm}$ is started, the reverse voltammetric scan displays an anodic current up to the crossover potential value (Fig. 7). Further on, the rest of the voltammogram shows peaks $I_{c}$ and $\mathrm{II}_{\mathrm{c}}$, the corresponding charges being appreciably diminished as compared to those resulting in still solution. Likewise, a considerable increase of the cathodic current baseline related to the electroreduction of soluble $\mathrm{Cu}$ (II) species can be noted. These results demonstrate that in the presence of $\mathrm{NaHCO}_{3}$ the increase in the anodic current produced throughout stirring is related to an enhancement of the $\mathrm{Cu}$ electrodissolution current. However, the dissolution of the anodic layer caused by the presence of $\mathrm{HCO}_{3}^{-}$ions reaches a limit for $\omega \geqslant 500 \mathrm{rpm}$. Thence, the cathodic charge related to peaks $\mathrm{II}_{c}$ and $\mathrm{III}_{c}$ can be considered as a measure of the amount of anodic layer formed under those circumstances.

On the other hand, the dissolution of the anodic layer in solutions containing $\mathrm{HCO}_{3}^{-}$produces a local acidification at the interface which is reflected in the positive potential shifts of peaks $\mathrm{I}_{c}$ and $\mathrm{II}_{c}$ (Figs 3 and 7). This effect is somewhat mitigated by the presence of the borate solution.

The preceding results definitely point out that the magnitude of the baseline cathodic current resulting for $\mathrm{Cu}$ specimens in $\mathrm{NaHCO}_{3}+\mathrm{Na}_{2} \mathrm{CO}_{3}$ solutions depends on the amount of soluble $\mathrm{Cu}$ (II) species present in the solution, on $E_{s s}, v$ and cycling time.

\subsection{Potentiostatic current transients}

3.2.1. Anodic current transients. The anodic current transients were obtained by setting the

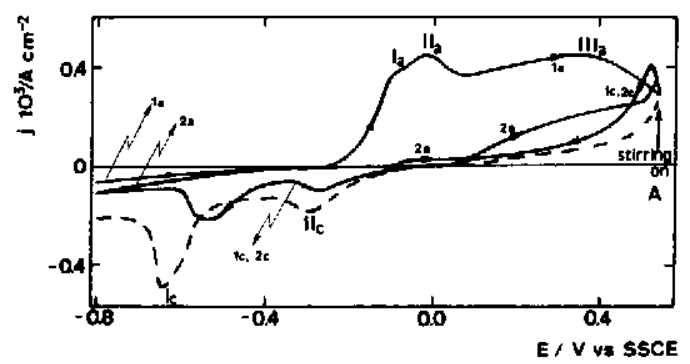

Fig. 7. Cyclovoltammograms run for $\mathrm{Cu}$ specimens (type ii); borate buffer $+0.1 \mathrm{M} \mathrm{NaHCO}, 25^{\circ} \mathrm{C}$. The voltammetric sweep commences at $-0.8 \mathrm{~V}$. The sequence of the sweeps is: 1a (quiescent solution); $1 \mathrm{c} ; 2 \mathrm{a}$; and $2 \mathrm{c}$ (under stirring at $1000 \mathrm{rpm}$ ). Stirring was started when the potential sweep reached point $A$. The dashed line corresponds to the cathodic profile recorded in the absence of stirring. potential at different $E_{8}$ values located in the potential range of either peak $I_{2}$ or peak $I_{2}$. According to the purpose of the experiments, each $\mathrm{Cu}$ specimen was first held $3 \mathrm{~min}$ at a potential $E_{c}\left(E_{\mathrm{c}}<E_{\mathrm{g}}\right)$ to assure the electroreduction of the anodic layer either to $\mathrm{Cu}$ or to $\mathrm{Cu}_{2} \mathrm{O}$. Subsequently, the potential was stepped to $E_{\mathrm{s}}$, to build up anodic products, and the current transient was recorded simultaneously (Fig. 8). Similar runs were also made at different $\mathrm{pH}$ values. In all cases the current transients exhibit an initial current jump followed by a continuous current decrease to approach a constant residual value.

3.2.2. Cathodic current transients. The following potential routine was applied for recording the cathodic current transients. Each $\mathrm{Cu}$ specimen was first held $3 \mathrm{~min}$ to $E_{\mathrm{c}}\left(E_{\mathrm{c}}>E_{\mathrm{g}}\right)$ to assure the electroreduction of the anodic layer. Subsequently, the potential was stepped to $E_{\mathrm{a}}$, a potential within the

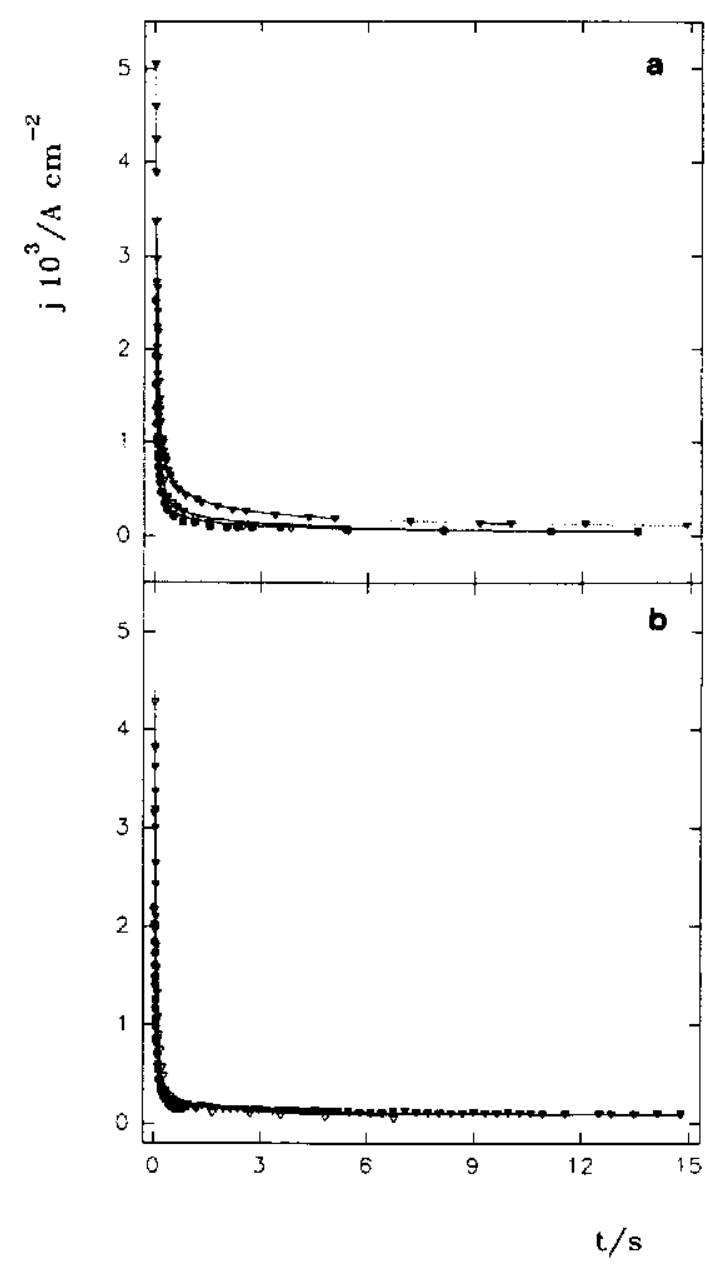

Fig. 8. Anodic current transients recorded under different experimental conditions: (a) values of $E_{\mathrm{s}}$ set in the potential range of peak $I_{\mathrm{a}} ;(0) \mathrm{pH} \mathrm{8.8,} E_{\mathrm{k}}=-0.13 \mathrm{~V},(\nabla) \mathrm{pH} 9.8$, $E_{\mathrm{s}}=-0.16 \mathrm{~V}$, (V) $\mathrm{pH} 11.1, E_{\mathrm{s}}=-0.21 \mathrm{~V}$; (b) $E_{\mathrm{s}}$ values set in the potential range of peak $\mathrm{II}_{\mathrm{s}} ;(0) \mathrm{pH} 8.8, E_{\mathrm{s}}=0.20 \mathrm{~V}$, (V) $\mathrm{pH} 9.8, E_{\mathrm{s}}=0.06 \mathrm{~V},(\nabla) \mathrm{pH} 11.1, E_{\mathrm{s}}=0.05 \mathrm{~V}$. The symbols denote the experimental data and the lines correspond to the current transients calculated with equations (8) $-(10)$. 


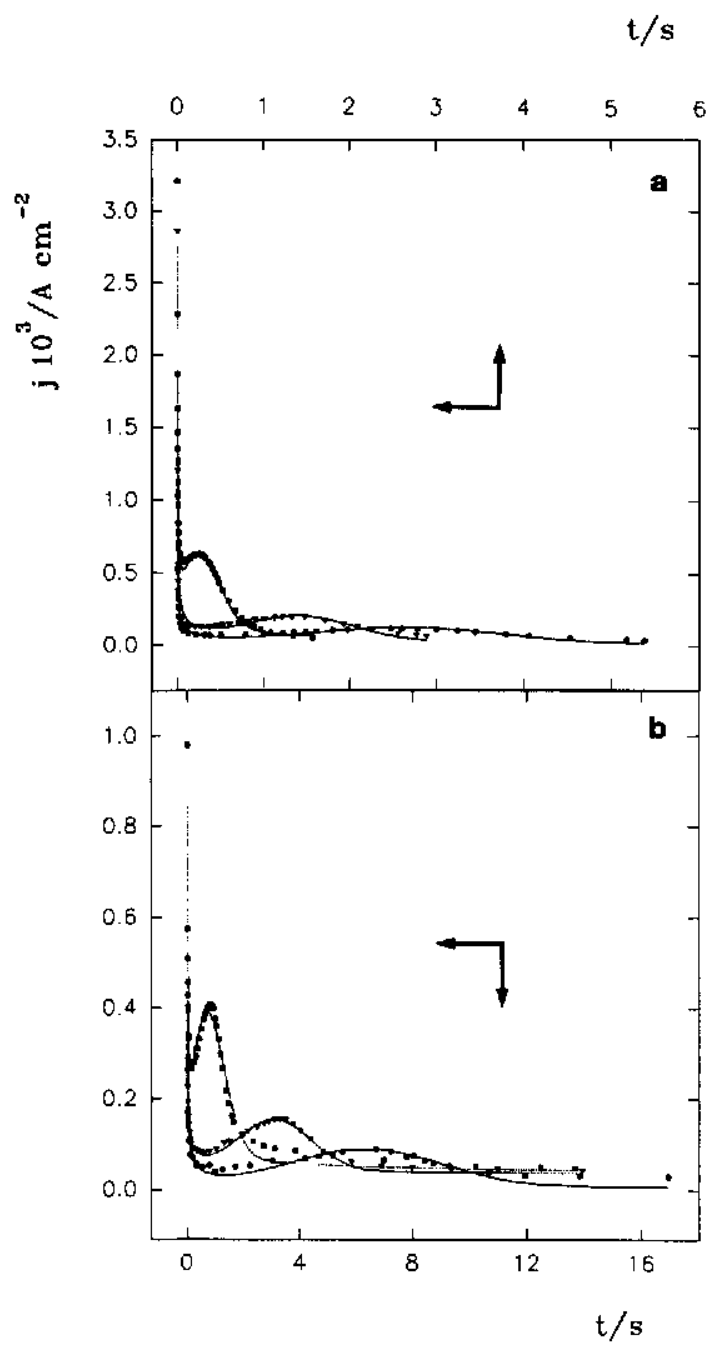

Fig. 9. Cathodic current transients recorded under different experimental conditions: (a) $0.1 \mathrm{M} \mathrm{NaHCO}, \mathrm{pH} \mathrm{8.8,} E_{2}=$ $0.12 \mathrm{~V}$ for $100 \mathrm{~s}$ and the following $E_{\mathrm{g}}$ values, $(O)-0.13 \mathrm{~V}$, ( $\nabla)-0.16 \mathrm{~V},(\nabla)-0.23 \mathrm{~V}$; (b) $0.1 \mathrm{M} \mathrm{Na} \mathrm{CO}_{3}, \mathrm{pH} 11.1$, $E_{\mathrm{a}}=0.01 \mathrm{~V}$ for $100 \mathrm{~s}$ and the following $E_{\mathrm{s}}$ values (O) $-0.18 \mathrm{~V},(\nabla)-0.20 \mathrm{~V},(\nabla)-0.25 \mathrm{~V} .25^{\circ} \mathrm{C}$.

anodic current plateau (III) for growing the anodic layer during $100 \mathrm{~s}$. Finally, the electroreduction current transients were run at a preset $E_{\mathrm{a}}$ value. The latter was set within the potential range of peak $\mathrm{II}_{c}$. The values of $E_{\mathrm{c}}$ and $E_{\mathrm{a}}$ were adequately chosen according to the composition of the solution.

The cathodic current transients show an initial cathodic current decrease approaching a linear $j$ vs. $t^{-1 / 2}$ relationship, and then a current increase up to a maximum value $\left(j_{M}\right)$ at time $t_{M}$, and finally a monotonous decrease to attain a small value (Fig. 9). The value of $j_{M}$ increases and the value of $t_{M}$ decreases as $E_{\mathrm{s}}$ is shifted negatively. The values $\ln j_{M, \text { Ilc }}$, after correction for the current baseline corresponding to each experiment $\left(j_{\mathrm{r}}\right)$, plotted against $E_{\mathrm{s}}$ (Fig. 10) approach a straight line with a slope close to $2 R T / F$ for $E_{\mathrm{s}} \geqslant 0.25 \mathrm{~V}$. This behaviour is also observed when either $E_{\mathrm{a}}$ or $\mathrm{t}_{\mathrm{a}}$ is fixed as the independent variable in the experiment. Data displayed in

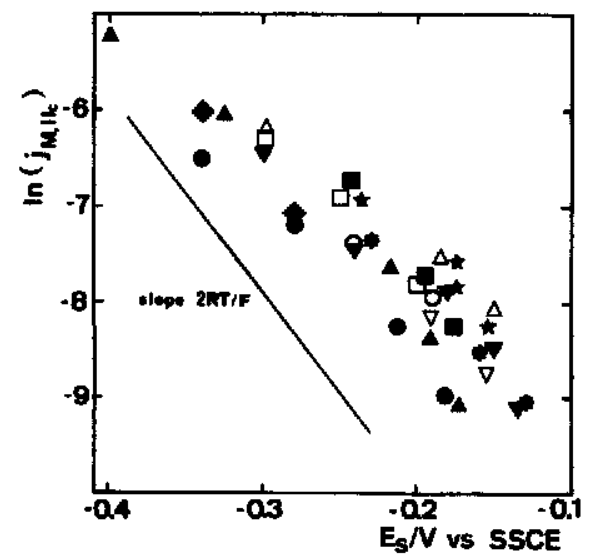

Fig. 10. Ln $j_{M . ~ l l c}$ vs. $E$ s plot related to the cathodic current transients after correction for the residual current. Symbols correspond to the following experimental conditions: $0.1 \mathrm{M}$ $\mathrm{NaHCO}_{3}$; (O) $E_{\mathrm{a}}=0.104 \mathrm{~V}, t_{\mathrm{a}}=50 \mathrm{~s} ;(\nabla) E_{\mathrm{a}}=0.104 \mathrm{~V}$, $t_{\mathrm{a}}=100 \mathrm{~s} ;(\mathrm{V}) E_{\mathrm{a}}=0.106 \mathrm{~V}, t_{\mathrm{n}}=100 \mathrm{~s} ;$ (*) $E_{\mathrm{a}}=0.122 \mathrm{~V}$, $\left.t_{\mathrm{a}}=100 \mathrm{~s} ;(\star)\right) E_{\mathrm{a}}=0.250 \mathrm{~V}, t_{\mathrm{a}}=100 \mathrm{~s} ;$ (O) $E_{\mathrm{a}}=0.495 \mathrm{~V}$, $t_{\mathrm{a}}=100 \mathrm{~s} ; 0.05 \mathrm{M} \mathrm{NaHCO}+0.05 \mathrm{M} \mathrm{Na}_{2} \mathrm{CO}_{3},(\Delta) E_{\mathrm{a}}=$

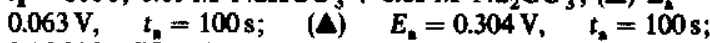
$0.1 \mathrm{M} \mathrm{Na}_{2} \mathrm{CO}_{3}$, (口) $E_{\mathrm{a}}=0.0 \mathrm{~V}, t_{\mathrm{k}}=50 \mathrm{~s}$; (D) $E_{\mathrm{s}}=0.01 \mathrm{~V}$, $t_{\mathrm{a}}=100 \mathrm{~s} ;(\bullet) E_{\mathrm{c}}=0.25 \mathrm{~V}, t_{\mathrm{a}}=100 \mathrm{~s}$. The straight line indicates the reference slope $2 R T / F$.

Fig. 10 suggest a change in the kinetics of the electroreduction reaction as $E_{\mathrm{s}}$ is moved negatively.

\subsection{SEM micrographs}

In all cases the SEM micrographs after the electrochemical treatment exhibit $\mathrm{Cu}$ surfaces coated by non-uniform corrosion products layers (Fig. 11a, b). The film exhibits crystalline nodules whose density seemingly decreases as the $\mathrm{pH}$ is increased. For mechanically polished $\mathrm{Cu}$ specimens in contact with $0.1 \mathrm{M} \mathrm{NaHCO}_{3}$ the scratches disappear at uncoated surface patches (Fig. 11a), but they are clearly observed in $0.1 \mathrm{M} \mathrm{Na}_{2} \mathrm{CO}_{3}$ (Fig. 11b). These results reveal that the depth of the localized attack increases as the $\mathrm{pH}$ of the solution is decreased. The SEM micrographs obtained in $0.5 \mathrm{M} \mathrm{NaHCO}+3.0 .5 \mathrm{M}$ $\mathrm{Na}_{2} \mathrm{CO}_{3}$ (Fig. 11c) shows a $\mathrm{Cu}$ surface partially coated by corrosion products. In this case the precipitate resembles that obtained on the $\mathrm{Cu}$ surface oxidized in a similar electrolyte for $20 \mathrm{~min}$ at $0.8 \mathrm{~V}$ which has been attributed to malachite[20].

The SEM micrographs of specimens cycled in the $\mathrm{I}_{a}-\mathrm{II}_{a}$ and $\mathrm{I}_{c}-\mathrm{II}_{c}$ potential ranges in $0.1 \mathrm{M} \mathrm{Na} \mathrm{CO}_{2}$ (Fig. 11d), show a crystalline precipitate which can be assigned to $\mathrm{Cu}$ hydroxide[25].

\section{DISCUSSION}

The electrochemical behaviour of $\mathrm{Cu}$ in aqueous solutions containing $\mathrm{CO}_{3}^{2-}$ and $\mathrm{HCO}_{3}^{-}$ions[13] comprises the anodic formation of the inner $\mathrm{Cu}_{2} \mathrm{O}$ layer (peak $\mathrm{I}_{2}$ ) followed by the electroformation of an outer layer (peak $\mathrm{II}_{2}$ ) involving $\mathrm{CuO} / \mathrm{Cu}(\mathrm{OH})_{2}$ and basic $\mathrm{Cu}$ carbonates. The $\mathrm{Cu}(\mathrm{OH})_{2} /$ basic $\mathrm{Cu}$ carbonates ratio depends on both the solution composition and the applied anodic potential routine. 

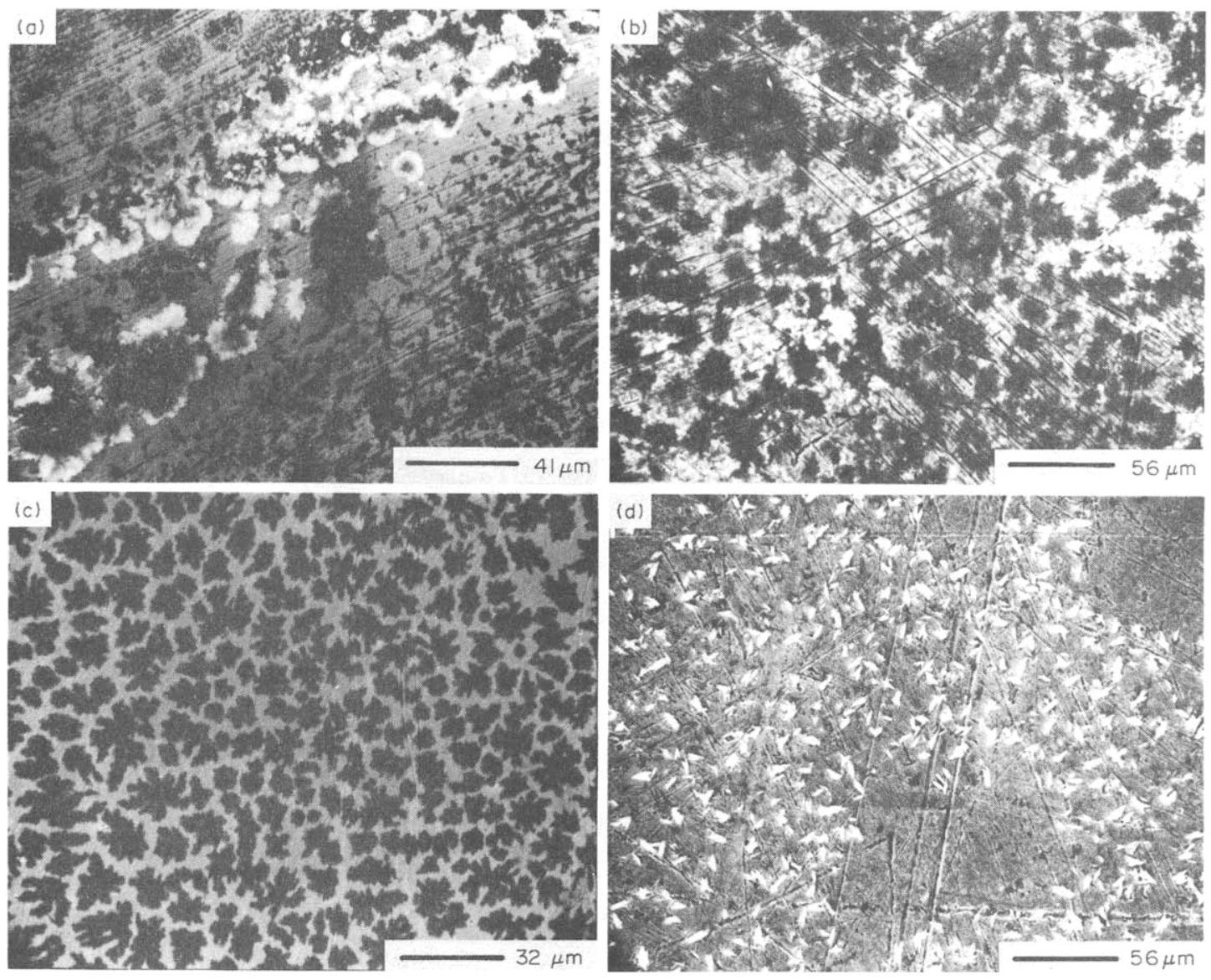

Fig. 11. SEM micrographs of Cu specimens (type i) which have been subjected to a potential cycling between $E_{\mathrm{sc}}$ and $E_{\mathrm{sa}}$ at $0.01 \mathrm{~V} \mathrm{~s}^{-1}$ : (a) $0.1 \mathrm{M} \mathrm{NaHCO}, \mathrm{pH} 8.8, E_{\mathrm{sc}}=-0.75 \mathrm{~V}, E_{\mathrm{az}}=0.35 \mathrm{~V}$; (b) $0.1 \mathrm{M}$ $\mathrm{Na}_{2} \mathrm{CO}_{3}, \mathrm{pH} 11.1, E_{\mathrm{sc}}=-0.75 \mathrm{~V}, E_{\mathrm{sa}}=0.50 \mathrm{~V}$; (c) $0.05 \mathrm{M} \mathrm{NaHCO}_{3}+0.05 \mathrm{M} \mathrm{Na}_{2} \mathrm{CO}_{3}, \mathrm{pH} \mathrm{9.2,} E_{\mathrm{sc}}=$ $-0.75 \mathrm{~V}, E_{\mathrm{sa}}=0.55 \mathrm{~V}$; (d) $0.1 \mathrm{M} \mathrm{Na}_{2} \mathrm{CO}_{3}, E_{\mathrm{sc}}=-0.40 \mathrm{~V}, E_{\mathrm{sa}}=0.0 \mathrm{~V}$. The bars indicate the scale in micrometers.

The voltammograms systematically show that $q_{1 a}$, the anodic charge of peak $I_{a}$, exceeds $q_{\mathrm{lc}}$, the cathodic charge of peak $I_{c}$ (Figs 3,6 and 7). Therefore, only a part of the anodic charge appears as $\mathrm{Cu}_{2} \mathrm{O}$ layer, and the difference $\Delta q_{\mathrm{a}}=q_{\mathrm{a}}-q_{\mathrm{c}}$ results in the formation of soluble $\mathrm{Cu}(\mathrm{II})$ species. The baseline cathodic current extending from $E_{\text {rey }}=$ $(0.299-0.059 \mathrm{pH})$ to $E_{\mathrm{sc}}$, and the residual current observed in the cathodic current transients (Fig. 9) correspond to the electroreduction of soluble $\mathrm{Cu}$ (II) species. The contribution of the latter gradually increases as $E_{\mathrm{s}}$ is shifted positively. This means that the $\mathrm{Cu}$ (II) soluble species originates in the same potential range where reactions yielding $\mathrm{Cu}_{2} \mathrm{O}$, and $\mathrm{CuCO}_{3}$ and basic $\mathrm{CuCO}_{3}$ takes place.

The early formation of $\mathrm{CuCO}_{3}$ in the anodization of $\mathrm{Cu}$ in $\mathrm{NaHCO}_{3}+\mathrm{Na}_{2} \mathrm{CO}_{3}$ solutions has been concluded from Electron Microprobe Analysis data[13], and it can proceed immediately after the initial $\mathrm{Cu}$ electro-oxidation process. The global reactions can be represented as follows

$$
\begin{gathered}
\mathrm{Cu}+\mathrm{H}_{2} \mathrm{O}=\mathrm{Cu}(\mathrm{OH})_{\text {ad }}+\mathrm{H}^{+}+\mathrm{e}^{-}, \\
\mathrm{Cu}(\mathrm{OH})_{\mathrm{ad}}+\mathrm{HCO}_{3}^{-}=\mathrm{CuCO}_{3}+\mathrm{H}_{2} \mathrm{O}+\mathrm{e}^{-}
\end{gathered}
$$

or

$$
\begin{gathered}
2 \mathrm{Cu}+\mathrm{H}_{2} \mathrm{O}=\mathrm{Cu}_{2} \mathrm{O}+2 \mathrm{H}^{-}+2 \mathrm{e}^{-}, \\
\mathrm{Cu}_{2} \mathrm{O}+2 \mathrm{HCO}_{3}^{-}=2 \mathrm{CuCO}_{3}+\mathrm{H}_{2} \mathrm{O}+2 \mathrm{e}^{-},
\end{gathered}
$$

followed by the formation of $\mathrm{Cu}(\mathrm{II})$ soluble species according to $[20]$ :

$$
\mathrm{CuCO}_{3}+\mathrm{HCO}_{3}^{-}=\left[\mathrm{Cu}\left(\mathrm{CO}_{3}\right)_{2}\right]^{2-}+\mathrm{H}^{+} .
$$

At $\mathrm{pH} 8$ the stable forms of $\mathrm{Cu}$ are $\mathrm{Cu}_{2} \mathrm{O}$ and $\mathrm{CuCO}_{3}$ (malachite), the relative amount of these substances depending on the concentration of $\mathrm{HCO}_{3}^{-}$ ions. There is no evidence that an appreciable amount of soluble $\mathrm{Cu}$ (II) species could be formed through a disproportionation reaction involving $\mathrm{Cu}(\mathrm{I})$ species resulting in the first electro-oxidation reaction.

As the potential increases further the formation of $\mathrm{Cu}(\mathrm{OH})_{2}$ (peak $\mathrm{II}_{\mathrm{a}}$ ) takes place yielding basic $\mathrm{Cu}(\mathrm{II})$ carbonates according to reactions such as:

$$
\begin{aligned}
& \mathrm{Cu}_{2} \mathrm{O}+\mathrm{HCO}_{3}^{-}+\mathrm{H}_{2} \mathrm{O} \\
& =\left[\mathrm{Cu}(\mathrm{OH})_{2} \cdot \mathrm{CuCO}_{3}\right] \text { (malachite) }+\mathrm{H}^{+}+2 \mathrm{e}^{-},
\end{aligned}
$$




$$
\begin{aligned}
& 3 \mathrm{Cu}_{2} \mathrm{O}+2 \mathrm{HCO}_{3}^{-}+\mathrm{H}_{2} \mathrm{O} \\
& =2\left[\mathrm{Cu}(\mathrm{OH})_{2} \cdot 2 \mathrm{CuCO}_{3}\right] \quad \text { (azurite) }+2 \mathrm{H}^{+}+2 \mathrm{e}^{-} .
\end{aligned}
$$

The composition of the $\mathrm{Cu}$ (II) basic carbonate layer should depend on the $\mathrm{pH}$ of the solution. The stability constants of malachite $\left[\mathrm{CuCO}_{3} \cdot \mathrm{Cu}(\mathrm{OH})_{2}\right]$ and azurite $\left[2 \cdot \mathrm{CuCO}_{3} \cdot \mathrm{Cu}(\mathrm{OH})_{2}\right]$ are $\log \mathrm{K}=33.78$ and $\log K=45.96$ at $25^{\circ} \mathrm{C}[26,27]$.

The present results also reveal that the yield of soluble $\mathrm{Cu}$ (II) species can be strongly increased through stirring in solutions containing $\mathrm{NaHCO}_{3}$. Then, the dissolution of the anodic layer can proceed through the following reactions:

$$
\begin{aligned}
& {\left[\mathrm{CuCO}_{3} \cdot \mathrm{Cu}(\mathrm{OH})_{2}\right]+3 \mathrm{HCO}_{3}^{-}} \\
& =2\left[\mathrm{Cu}\left(\mathrm{CO}_{3}\right)_{2}\right]^{2-}+2 \mathrm{H}_{2} \mathrm{O}+\mathrm{H}^{+}, \\
& {\left[\mathrm{CuCO}_{3} \cdot \mathrm{Cu}(\mathrm{OH})_{2}\right]+\mathrm{HCO}_{3}^{-}+\mathrm{H}_{2} \mathrm{O}} \\
& =2\left[\mathrm{CuCO}_{3}(\mathrm{OH})_{2}\right]^{2-}+3 \mathrm{H}^{+}
\end{aligned}
$$

and

$$
\begin{aligned}
& {\left[\mathrm{Cu}(\mathrm{OH})_{2} \cdot 2 \mathrm{CuCO}_{3}\right]+4 \mathrm{HCO}_{3}^{-}} \\
& =3\left[\mathrm{Cu}\left(\mathrm{CO}_{3}\right)_{2}\right]^{2-}+2 \mathrm{H}_{2} \mathrm{O}+2 \mathrm{H}^{+}, \\
& {\left[\mathrm{Cu}(\mathrm{OH})_{2} \cdot 2 \mathrm{CuCO}_{3}\right]+\mathrm{HCO}_{3}^{-}+4 \mathrm{H}_{2} \mathrm{O}} \\
& =3\left[\mathrm{CuCO}_{3}(\mathrm{OH})_{2}\right]^{2-}+5 \mathrm{H}^{+} .
\end{aligned}
$$

The conclusive influence of $\mathrm{HCO}_{3}^{-}$for destroying the anodic layer formed on $\mathrm{Cu}$ is observed for those specimens passivated in borate buffer (Figs 6 and 7). Reactions (5)-(6) imply the formation of $\mathrm{Cu}$ carbonate soluble complexes and simultaneous local acidification of the interface. The contribution of these reactions decreases as the $\mathbf{p H}$ of the solution is increased. Therefore, the cathodic baseline seen in the voltammogram can be explained as the electroreduction of the soluble $\mathrm{Cu}$ complexes formed through reactions $(5)-(6)$.

The influence of $\omega$ on the anodic current read at $E=0.45 \mathrm{~V}$ can be clearly seen in Fig. 6 . In this case, the quasi-steady current resulting at $\omega=500 \mathrm{rpm}$ indicates that at this potential the electroformation and the chemical dissolution of the anodic layer happen at nearly equal rates. The anodic limiting current density, $8 \times 10^{-4} \mathrm{~A} \mathrm{~cm}^{-2}$, is equivalent to a $\mathrm{Cu}$ dissolution rate equal to $4.2 \times 10^{-9} \mathrm{~mol} \mathrm{~cm}^{-2} \mathrm{~s}^{-1}$. Accordingly, the residual anodic current resulting from the current transients provides an indication of the protective characteristics of the anodic layer formed on $\mathrm{Cu}$ in the different solutions at comparable $\mathrm{pH}$ and applied potential conditions. Thus, the residual anodic current read at $0.2 \mathrm{~V}$ decreases from $0.15 \mathrm{~mA} \mathrm{~cm}^{-2}$ for $\mathrm{pH} 8.8$ to $0.087 \mathrm{~mA} \mathrm{~cm}^{-2}$ for $\mathrm{pH} 11.1$. The preceding conclusions agree with those recently reported for the electrochemical behaviour of $\mathrm{Cu}$ in solutions containing $\mathrm{NaHCO}_{3}[20]$ in the $0.001-0.1 \mathrm{M}$ range.

\subsection{The interpretation of anodic current transients}

The formation of the anodic layer on $\mathrm{Cu}$ in solutions containing $\mathrm{NaHCO}_{3}+\mathrm{Na}_{2} \mathrm{CO}_{3}$ can be interpreted in terms of nucleation and growth models applicable to the formation of new phases at the metal/solution interface $[8,15,28,29]$. In the present work, the anodic current transients depend whether the electro-oxidation potential step covers the potential range of either peak $I_{a}$ or peak $I_{a}$. In the former case the anodic layer grows either on base $\mathrm{Cu}$ or on a $\mathrm{Cu}$ surface covered by a $\mathrm{Cu}(\mathrm{OH})_{\text {ad }}$ monolayer; whereas for the second case the $\mathrm{Cu}$ surface is already coated by a $\mathrm{Cu}_{2} \mathrm{O} / \mathrm{CuCO}_{3}$ layer, and the anodic process leads to the thickening of the anodic layer. The apparent anodic current density, $j_{1}$, in both cases can be associated with several contributions, namely a term $j_{\mathrm{d} 1}$ associated with the double layer charging; a term $j_{\mathrm{p}}$ related to the proper anodic layer growth; and a term $j_{\mathrm{d}}$ resulting from the balance of the metal dissolution through the anodic layer and the chemical dissolution of the anodic layer itself. Thus,

$$
j_{\mathrm{t}}=j_{\mathrm{d} \mathbf{l}}+j_{\mathrm{p}}+j_{\mathrm{d}} .
$$

Under the present circumstances the double layer charging component quickly drops to zero in time, therefore, its contribution in equation (7) can be neglected. Then, equation (7) reduces to

$$
j_{\mathrm{t}}=j_{\mathrm{p}}+j_{\mathrm{d}} \text {. }
$$

As a first approach one can also describe the growth of the anodic layer as an instantaneous nucleation and two-dimensional growth under diffusion control. The corresponding rate equation is [30]:

$$
j_{\mathrm{p}}=P_{1} \exp \left(-P_{2} t\right)
$$

where

$$
\begin{aligned}
P_{1} & =q \pi K D N_{0}, \\
P_{2} & =\pi K D N_{0}, \\
P_{1} / P_{2} & =q,
\end{aligned}
$$

$q$ is the charge density involved in the anodic layer formation, $K$ is a proportionality constant, $D$ is the diffusion coefficient of the species involved in the anodic layer growth and $N_{0}$ is the number of sites available for nucleation. It should be noted that a similar equation has been derived for multilayer growth by adsorption [31].

On the other hand, $\mathrm{Cu}$ electrodissolution can be assigned to the diffusion of $\mathrm{Cu}(\mathrm{II})$ ions from the metal surface through the anodic layer to the solution. For this process the equation is:

$$
j_{\mathrm{d}}=P_{3} t^{-1 / 2},
$$

where

$$
P_{3}=z F D^{* 1 / 2} \Delta c \pi^{-1 / 2},
$$

and $D^{*}$ has the same meaning as before, but applied to the conditions of the new process, and $\Delta c$ is the concentration gradient associated with the $\mathrm{Cu}$ electrodissolution process through the anodic layer. The linear $\ln j_{\mathrm{p}}$, Ia vs. $\ln v$ relationships with slopes approaching 0.5 which were observed in this case, are consistent with a solid phase diffusion controlled $\mathrm{Cu}$ electrodissolution.

By using equations (8)-(10) the current transients recorded in the potential range of peak $\mathrm{I}_{\mathrm{a}}$ (Fig. 8a) 
and peak $\mathrm{II}_{\mathrm{a}}$ (Fig. 8b) at different $\mathrm{pH}$ can be reproduced with the set of parameters assembled in Table 1. These parameters contain valuable information about the characteristics of the anodic processes.

The value of $P_{1}$ becomes nearly independent on the $\mathrm{NaHCO}_{3} / \mathrm{Na}_{2} \mathrm{CO}_{3}$ concentration ratio; whereas $\boldsymbol{P}_{2}$ depends on the solution composition, its lowest value resulting in $0.1 \mathrm{M} \mathrm{NaHCO}_{3}$ (pH 8.8). This fact is consistent with the anodic layer dissolving properties of $\mathrm{HCO}_{3}^{-}$ions. From $P_{1} / P_{2}=q$, the charge density related to the anodic layer growth can be obtained. For the solutions containing $\mathrm{Na}_{2} \mathrm{CO}_{3}$ and $\mathrm{NaHCO}_{3}+\mathrm{Na}_{2} \mathrm{CO}_{3}$ the value of $q$ approaches the $\mathrm{Cu}(\mathrm{OH})_{\text {ad }}$ monolayer charge density $\left(q \cong 0.37 \mathrm{mC} \mathrm{cm}^{-2}\right)[32]$, whereas for solutions containing $\mathrm{NaHCO}_{3}, q$ is about twice. The same figure can be also derived from the voltammetric charge density related to peak $I_{a}$. Therefore, it is reasonable to admit that the charge density involved in $j_{\mathrm{p}}$ corresponds only to that required for the building up the inner $\mathrm{Cu}_{2} \mathrm{O}$ layer. These results are coherent with the formation of $\mathrm{CuCO}_{3}$ from the initial stages of the anodization process as referred to in the preceding section.

Otherwise, the value of $P_{3}$ increases with decreasing $\mathrm{pH}$ as one should expect for the $\mathrm{HCO}_{3}^{-}$ion assisted dissolution of the anodic layer. Other comparable electrochemical systems such as the anodic layer formation on $\mathrm{Cu}$ in phosphate solutions [15] obey the same mechanism, but the presence of $\mathrm{HCO}_{3}^{-}$ions in the solution increases considerably the value of $P_{3}$. Accordingly, the residual $\mathrm{Cu}$ electro- dissolution current in $\mathrm{NaHCO}_{3}$ solution becomes greater than in phosphate solution[15].

The physical picture involved in the preceding model can be summarized as follows. A small part of the anodic charge belongs to the inner $\mathrm{Cu}_{2} \mathrm{O}$ passive layer. The accumulation of this charge occurs for $t<5 \mathrm{~s}$ and it can be associated with $j_{\mathrm{p}}$. Another part of the anodic charge is related to a $\mathrm{Cu}$ electrodissolution process involving the diffusion of $\mathrm{Cu}$ (II) ions from the metal/inner oxide layer to the inner oxide layer/solution interface. This process is slow and can be associated with the term $j_{d}$. Besides, when the potential exceeds the potential range of peak $\mathrm{II}_{\mathrm{a}}$ the anodic charge is used up in part to grow the outer $\mathrm{CuO} / \mathrm{Cu}(\mathrm{OH})_{2}-\mathrm{CuCO}_{3}$ complex layer, and in part to form soluble $\mathrm{Cu}$ (II) species. However, equation (8) predicts a $j$ vs. $t^{-1 / 2}$ law which for $t>10 \mathrm{~s}$ is not observed, as $j_{\mathrm{t}}$ becomes then practically constant. This apparent discrepancy can be explained considering that for $t \geqslant 5 s, j_{\mathrm{p}} \geqslant 0$ and $h$, the layer thickness, becomes practically constant. Then, the diffusion layer thickness becomes equal to $h$ and $j_{\mathrm{d}}$ becomes constant. This residual current can be interpreted as $\mathrm{Cu}$ corrosion current through a constant thickness $\mathrm{Cu}_{2} \mathrm{O} / \mathrm{CuO} / \mathrm{Cu}(\mathrm{OH})_{2}-\mathrm{CuCO}_{3}$ layer.

\subsection{The interpretation of cathodic current transients}

In the presence of $\mathrm{NaHCO}_{3}$ and $\mathrm{Na}_{2} \mathrm{CO}_{3}$ in the solution the anodic layers formed on $\mathrm{Cu}$ specimens can be described as a composed structure consisting of an inner $\mathrm{Cu}_{2} \mathrm{O}-\mathrm{CuOH}$ layer, and intermediate

Table 1. Parameters used for adjusting the $\mathrm{Cu}(\mathrm{O}) / \mathrm{Cu}(\mathrm{I})$ and $\mathrm{Cu}(\mathrm{I}) / \mathrm{Cu}(\mathrm{II})$ anodic current transients

\begin{tabular}{|c|c|c|c|c|c|}
\hline Solution & $\begin{array}{l}E_{\mathrm{c}} \\
(\mathrm{V})\end{array}$ & $\begin{array}{r}E_{\mathrm{g}} \\
(\mathrm{V})\end{array}$ & $\begin{array}{c}10^{4} P_{1} \\
\left(\mathrm{~A} \mathrm{~cm}^{-2}\right)\end{array}$ & $\begin{array}{c}P_{2} \\
\left(\mathrm{~s}^{-1}\right)\end{array}$ & $\left(\begin{array}{c}10^{4} P_{3} \\
\left(\mathrm{As}^{1 / 2} \mathrm{~cm}^{-2}\right)\end{array}\right.$ \\
\hline \multicolumn{6}{|c|}{ First electro-oxidation stage } \\
\hline \multirow[t]{3}{*}{$0.1 \mathrm{M} \mathrm{Na}_{2} \mathrm{CO}_{3}$} & -0.627 & -0.305 & 13.7 & 20.2 & 3.19 \\
\hline & & -0.250 & 17.6 & 13.0 & 3.57 \\
\hline & & -0.205 & 36.5 & 10.4 & 2.49 \\
\hline \multirow{3}{*}{$\begin{array}{c}0.05 \mathrm{M} \mathrm{NaHCO} \mathrm{NaCO}_{3}+ \\
0.5 \mathrm{M} \mathrm{Na}_{2} \mathrm{CO}_{3}\end{array}$} & -0.650 & -0.250 & 22.1 & 56.0 & 1.93 \\
\hline & & -0.225 & 19.6 & 51.9 & 2.68 \\
\hline & & -0.157 & 21.7 & 18.2 & 3.44 \\
\hline \multirow[t]{2}{*}{$0.1 \mathrm{M} \mathrm{NaHCO}_{3}$} & -0.550 & -0.130 & 17.7 & 2.95 & 14.1 \\
\hline & & -0.160 & 16.8 & 1.97 & 9.23 \\
\hline \multicolumn{6}{|c|}{ Second electro-oxidation stage } \\
\hline \multirow[t]{6}{*}{$0.1 \mathrm{M} \mathrm{Na}_{2} \mathrm{CO}_{3}$} & -0.430 & -0.110 & 17.6 & 195 & 0.87 \\
\hline & & -0.073 & 5.13 & 331 & 1.61 \\
\hline & & -0.055 & 2.66 & 13.5 & 2.00 \\
\hline & & -0.035 & 9.67 & 9.70 & 1.76 \\
\hline & & 0.010 & 31.1 & 21.2 & 2.54 \\
\hline & & 0.250 & 130 & 37.3 & 7.02 \\
\hline \multirow{4}{*}{$\begin{array}{c}0.5 \mathrm{M} \mathrm{NaHCO}_{3}+ \\
0.5 \mathrm{M} \mathrm{Na}_{2} \mathrm{CO}_{3}\end{array}$} & -0.423 & 0.020 & 28.6 & 34.5 & 3.30 \\
\hline & & 0.035 & 36.7 & 27.7 & 2.97 \\
\hline & & 0.060 & 44.1 & 27.3 & 3.38 \\
\hline & & 0.305 & 151 & 30.8 & 3.64 \\
\hline \multirow[t]{8}{*}{$0.1 \mathrm{M} \mathrm{NaHCO}_{3}$} & -0.241 & 0.045 & 57.9 & 30.7 & 1.49 \\
\hline & & 0.082 & 8.03 & 6.67 & 0.58 \\
\hline & & 0.105 & 7.91 & 10.1 & 1.01 \\
\hline & & 0.200 & 19.2 & 17.4 & 1.26 \\
\hline & -0.350 & 0.016 & 2.00 & 5.85 & 0.99 \\
\hline & & 0.041 & 5.38 & 10.1 & 1.15 \\
\hline & & 0.105 & 13.8 & 17.9 & 1.46 \\
\hline & & 0.300 & 63.7 & 29.7 & 2.04 \\
\hline
\end{tabular}


$\mathrm{CuO}-\mathrm{Cu}(\mathrm{OH})_{2}$ layer, an outer $\mathrm{Cu}(\mathrm{OH})_{2}-\mathrm{CuCO}_{3}$ layer, the stoichiometry of the latter depending on the $\mathrm{pH}$ of the solution[2].

The electroreduction of the $\mathrm{Cu}$ (II) layers to $\mathrm{Cu}_{2} \mathrm{O}$ (or $\mathrm{CuOH}$ ) would proceed through the following global reaction:

$$
\begin{array}{r}
\mathrm{CuCO}_{3}-\mathrm{Cu}(\mathrm{OH})_{2} \text { layer }+2 \mathrm{e}^{-} \\
=\mathrm{Cu}_{2} \mathrm{O}+\mathrm{H}_{2} \mathrm{O}+\mathrm{CO}_{3}^{2-},
\end{array}
$$

which implies a solid phase change. The latter is likely responsible for the sharp peak $\mathrm{II}_{\mathrm{c}}^{\prime}$ appearing in the complex structure of peak $\mathrm{II}_{c}$. A process comparable to that represented by equation (11) has been earlier described for the electroreduction of $\mathrm{Cu}(\mathrm{OH})_{2}$ layers in plain $\mathrm{NaOH}$ solutions[9].

The intermediate $\mathrm{CuO}-\mathrm{Cu}(\mathrm{OH})_{2}$ layer can be also electroreduced to $\mathrm{Cu}_{2} \mathrm{O}$ according to global processes such as:

$$
2 \mathrm{CuO}+\mathrm{HCO}_{3}^{-}+2 \mathrm{e}^{-}=\mathrm{Cu}_{2} \mathrm{O}+\mathrm{CO}_{3}^{2-}+\mathrm{OH}^{-},
$$

$$
\begin{aligned}
2 \mathrm{Cu}(\mathrm{OH})_{2} & +\mathrm{HCO}_{3}^{-}+2 \mathrm{e}^{-} \\
= & \mathrm{Cu}_{2} \mathrm{O}+\mathrm{CO}_{3}^{2-}+\mathrm{OH}^{-}+2 \mathrm{H}_{2} \mathrm{O}
\end{aligned}
$$

and

$$
\begin{gathered}
2 \mathrm{Cu}(\mathrm{OH})_{2}+2 \mathrm{e}^{-}=\mathrm{Cu}_{2} \mathrm{O}+\mathrm{H}_{2} \mathrm{O}+2 \mathrm{OH}^{-}, \\
2 \mathrm{CuO}+\mathrm{H}_{2} \mathrm{O}+2 \mathrm{e}^{-}=\mathrm{Cu}_{2} \mathrm{O}+2 \mathrm{OH}^{-} .
\end{gathered}
$$

At high cathodic potentials $\left(E<E_{\mathrm{r}}\right)$ the electroreduction to $\mathrm{Cu}(\mathrm{O})$ can be related to the appearance of peak $I_{c}$ and the corresponding global reactions can be represented as follows:

$$
\mathrm{Cu}_{2} \mathrm{O}+\mathrm{H}_{2} \mathrm{O}+2 \mathrm{e}^{-}=2 \mathrm{Cu}+2 \mathrm{OH}^{-}
$$

and

$$
\mathrm{Cu}(\mathrm{OH})_{2}+2 \mathrm{e}^{-}=\mathrm{Cu}+2 \mathrm{OH}^{-} .
$$

At present the analysis of the cathodic current transients obtained at constant potential offers the possibility of modeling only the potentiostatic electroreduction of the $\mathrm{Cu}$ (II) anodic layers to $\mathrm{Cu}_{2} \mathrm{O}$ (peak $\mathrm{II}_{\mathrm{c}}$ ). The voltammograms related to this process are rather complex and revealed that several contributions are involved when the reaction proceeds in the potential range of peak $\mathrm{II}_{\mathrm{c}}$. Furthermore, the $\mathrm{pH}$ dependence of the potential of peak $\mathrm{II}_{\mathrm{c}}$ is greater than that expected for a reversible electrochemical reaction [see section 3.1.1]. The same conclusion about the complexity of the electroreduction processes can be derived from the shape of the potentiostatic current transients (Fig. 9).

As a first approach the potentiostatic electroreduction current transients can be modeled considering three main contributions:

$$
j_{\mathrm{cII}}=j_{\mathrm{ed}}+j_{\mathrm{cn}}+j_{\mathrm{r}},
$$

where $j_{\mathrm{cII}}$ is the total cathodic current density involved in the electroreduction process; $j_{\mathrm{cd}}$ is a diffusion controlled current density which is associated with the fast initial current decay; $j_{\text {en }}$ is a current density producing a maximum current value in the transient, which can be related to the nucleation and growth of a new phase in the passive layer; and $j_{\mathrm{r}}$ can be assigned to the electrodeposition current of residual soluble $\mathrm{Cu}(\mathrm{II})$ species. Thus, $j_{r}$ is given by:

$$
j_{r}=P_{4},
$$

and $j_{\mathrm{cd}}$ can be expressed:

$$
j_{\text {ed }}=P_{5} t^{-1 / 2}
$$

where

$$
P_{5}=z F D^{\# 1 / 2} \Delta c^{*} \pi^{-1 / 2}
$$

$D^{*}$ and $\Delta c^{*}$ are assigned to the diffusion coefficient and the concentration gradient of species entering the first electroreduction stage [reactions (13a) and (13b)].

On the other hand, the term $j_{c n}$ can be linked to the nucleation and two-dimensional growth of a new phase under charge transfer control [reaction (13)]. This assumption can be justified through the linear $\ln j_{M}$, It vs. $E_{s}$ plot approaching the slope $2 R T / F$ (Fig. 10). Thence, the corresponding current transient equations for an instantaneous nucleation are[33]:

where

$$
j_{\mathrm{cn}}=P_{6} t \exp \left(-P_{7} t^{2}\right)
$$

$$
\begin{aligned}
& P_{6}=2 z F \pi M h N_{0} k^{2} \rho^{-1}, \\
& P_{7}=\pi M^{2} N_{0} k^{2} \rho^{-2},
\end{aligned}
$$

and for a progressive nucleation is:

$$
j_{\mathrm{cn}}=P_{\mathrm{8}} t^{2} \exp \left(-P_{9} t^{3}\right)
$$

with

$$
\begin{aligned}
& P_{B}=2 F \pi M h A k^{2} \rho^{-1}, \\
& P_{9}=\pi M^{2} A k^{2}\left(3 \rho^{2}\right)^{-1} .
\end{aligned}
$$

$A$ is the nucleation rate, $k$ is the growth rate constant, $\rho$ is the specific gravity and $M$ is the molecular weight of the electroreduced species.

By using equations (16), (17) and (19) at low cathodic potentials, and equations (16)-(18) at high cathodic potentials, the current transients recorded in solutions containing $\mathrm{Na}_{2} \mathrm{CO}_{3}$ and $\mathrm{NaHCO}_{3}$ can be reproduced with the parameters assembled in Table 2.

According to data shown in Table 2, at low cathodic potentials the $\mathrm{Cu}(\mathrm{II}) / \mathrm{Cu}(\mathrm{I})$ electrochemical phase change can be described through the formalism of a progressive nucleation and a twodimensional phase growth mechanism; whereas at high cathodic potentials the process likely occurs through an instantaneous nucleation and a twodimensional phase change mechanism. These conclusions agree with the SEM micrographs resulting from the electroreduction process showing patches where the reaction takes place rather uniformly distributed on the electrode surface (Fig. 11).

At a constant solution composition the value of $P_{5}$ slightly increases as the value of $E_{8}$ is negatively increased. This trend, observed under different experimental conditions, may be assigned to either an increase of $\Delta c^{*}$ with $E_{s}$ or an electric fieldassisted transport of reaction products at the reaction layer. It should be noted that the charge density contribution related to $P_{5}$ is equivalent to about two monolayers of reactant. 
Table 2. Parameters used for adjusting the $\mathrm{Cu}(\mathrm{II}) / \mathrm{Cu}(\mathrm{I})$ cathodic current transients

\begin{tabular}{|c|c|c|c|c|c|c|c|}
\hline $\begin{array}{l}E_{n} \\
\text { (V) }\end{array}$ & $\begin{array}{l}t_{n} \\
(s)\end{array}$ & $\begin{array}{l}E_{8} \\
\text { (V) }\end{array}$ & $\begin{array}{c}10^{4} P_{\mathrm{s}} \\
\left(\mathrm{As}^{1 / 2} \mathrm{~cm}^{-2}\right)\end{array}$ & $\begin{array}{c}10^{4} P_{6} \\
\left(\mathrm{As}^{-1} \mathrm{~cm}^{-2}\right)\end{array}$ & $\begin{array}{c}P_{7} \\
\left(s^{-2}\right)\end{array}$ & $\begin{array}{c}10^{4} P_{8} \\
\left(\mathrm{~A} \mathrm{~s}^{-2} \mathrm{~cm}^{-2}\right)\end{array}$ & $\underset{\left(s^{-3}\right)}{P_{9}}$ \\
\hline \multicolumn{8}{|c|}{$0.1 \mathrm{M} \mathrm{Na}_{2} \mathrm{CO}_{3}$} \\
\hline 0 & 50 & $\begin{array}{l}-0.200 \\
-0.250 \\
-0.300\end{array}$ & $\begin{array}{l}0.52 \\
1.03 \\
1.24\end{array}$ & $\frac{-}{21.4}$ & $\frac{-}{7.62}$ & $\begin{array}{c}0.26 \\
8.48 \\
-\end{array}$ & $\begin{array}{l}0.033 \\
1.84 \\
-\end{array}$ \\
\hline 0.010 & 100 & -0.196 & 0.305 & - & - & 0.21 & 0.022 \\
\hline 0.250 & 100 & $\begin{array}{l}-0.245 \\
-0.340\end{array}$ & $\begin{array}{l}0.589 \\
2.26\end{array}$ & $\begin{array}{l}6.50 \\
13.6\end{array}$ & $\begin{array}{l}0.88 \\
1.28\end{array}$ & - & - \\
\hline \multicolumn{8}{|c|}{$0.05 \mathrm{M} \mathrm{NaHCO}+0.05 \mathrm{M} \mathrm{Na}_{2} \mathrm{CO}_{3}$} \\
\hline 0.063 & 100 & $\begin{array}{l}-0.150 \\
-0.185 \\
-0.300\end{array}$ & $\begin{array}{l}0.23 \\
0.38 \\
1.79\end{array}$ & $\frac{-}{187}$ & $\frac{-}{38.5}$ & $\begin{array}{c}1.14 \\
1.14 \\
-\end{array}$ & $\begin{array}{l}0.099 \\
1.11 \\
-\end{array}$ \\
\hline 0.304 & 100 & $\begin{array}{l}-0.173 \\
-0.192 \\
-0.217 \\
-0.325\end{array}$ & $\begin{array}{l}0.73 \\
0.92 \\
1.02 \\
2.88\end{array}$ & $\frac{-}{\overline{-}}$ & $\frac{-}{-}$ & $\begin{array}{l}0.013 \\
0.12 \\
1.71 \\
-\end{array}$ & $\begin{array}{c}0.014 \\
0.005 \\
0.085 \\
-\end{array}$ \\
\hline \multicolumn{8}{|c|}{$0.1 \mathrm{M} \mathrm{NaHCO}_{3}$} \\
\hline 0.104 & 50 & $\begin{array}{l}-0.151 \\
-0.190 \\
-0.241\end{array}$ & $\begin{array}{l}0.14 \\
0.29 \\
0.67\end{array}$ & $\begin{array}{r}-\overline{10.3} \\
37.6\end{array}$ & $\begin{array}{l}\overline{4.12} \\
18.7\end{array}$ & $\begin{array}{l}1.28 \\
-\end{array}$ & $\begin{array}{r}0.546 \\
- \\
-\end{array}$ \\
\hline & 100 & $\begin{array}{l}-0.150 \\
-0.190 \\
-0.241\end{array}$ & $\begin{array}{l}0.14 \\
0.26 \\
0.67\end{array}$ & $\begin{array}{l}\overline{9.74} \\
33.1\end{array}$ & $\begin{array}{c}\overline{2.83} \\
15.0\end{array}$ & $\begin{array}{c}0.89 \\
- \\
-\end{array}$ & $\begin{array}{r}0.28 \\
- \\
-\end{array}$ \\
\hline 0.106 & 100 & $\begin{array}{l}-0.135 \\
-0.150 \\
-0.180 \\
-0.300\end{array}$ & $\begin{array}{l}0.30 \\
0.14 \\
0.36 \\
1.49\end{array}$ & $\overline{-}$ & $\frac{-}{-}$ & $\begin{array}{c}0.19 \\
1.72 \\
20.7 \\
-\end{array}$ & $\begin{array}{l}0.026 \\
0.297 \\
4.65 \\
\end{array}$ \\
\hline 0.122 & 100 & $\begin{array}{l}-0.130 \\
-0.160 \\
-0.230\end{array}$ & $\begin{array}{l}0.36 \\
0.44 \\
0.873\end{array}$ & $\frac{-}{28.5}$ & $\frac{-}{6.43}$ & $\begin{array}{l}0.276 \\
1.70 \\
-\end{array}$ & $\begin{array}{l}0.034 \\
0.23 \\
-\end{array}$ \\
\hline 0.250 & 100 & $\begin{array}{l}-0.155 \\
-0.175 \\
-0.239\end{array}$ & $\begin{array}{l}0.937 \\
1.02 \\
1.48\end{array}$ & $\frac{-}{43.7}$ & $\frac{-}{6.45}$ & $\begin{array}{c}1.09 \\
5.24 \\
-\end{array}$ & $\begin{array}{r}0.11 \\
0.55 \\
-\end{array}$ \\
\hline 0.495 & 100 & $\begin{array}{l}-0.180 \\
-0.213 \\
-0.280\end{array}$ & $\begin{array}{l}0.636 \\
0.877 \\
1.46\end{array}$ & $\frac{-}{11.1}$ & $\frac{-}{\overline{0.72}}$ & $\begin{array}{c}0.021 \\
0.318 \\
-\end{array}$ & $\begin{array}{c}0.00075 \\
0.0143 \\
-\end{array}$ \\
\hline
\end{tabular}

On the other hand, the values of $P_{6}$ and $P_{8}$ and $P_{7}$ and $P_{9}$ also depend on $E_{3}$. The potential depen dence of these parameters should be principally assigned to the potential dependence of the corresponding $k$ values. Accordingly, the increase of those parameters with $E_{\mathrm{s}}$ would reflect the slowness of the process through the number of nucleation centers as expected from equations (19) and (20). Let us assume that under a particular set of experimental conditions, the potential dependence of the values, $k$ for the instantaneous nucleation, and the product $k A$ for the progressive nucleation, is given by a Tafel-type relationship with a transfer coefficient equal to 0.5 , ie $\left(\Delta \ln k / \Delta E_{s}\right)=2 R T / F$. For this case, the slopes of the $\ln P_{1}(i=6,7,8,9)$ vs. $E_{\mathrm{s}}$ plots should approach the slope $R T / F$. Despite data scattering, for constant solution composition and electrochemical routine conditions, the trend to approach the linear slope $R T / F$ is observed. For the cathodic process, the results are consistent with the potential dependence of $j_{\mathrm{M} .1 \mathrm{c}}$ as shown in Fig. 10.

Finally, the constant term $j_{\mathrm{r}}$ comprises the electrodeposition current of residual $\mathrm{Cu}$ (II) soluble species, and the magnitude of this contribution changes between $0.2 \times 10^{-4}$ and $0.5 \times 10^{-4} \mathrm{~A} \mathrm{~cm}^{-2}$, depending on the history of each run.

\section{CONCLUSIONS}

(i) The anodic layers formed on $\mathrm{Cu}$ in $\mathrm{NaHCO}_{3}$ $+\mathrm{Na}_{2} \mathrm{CO}_{3}$ solutions can be described as composed layers involving an inner $\mathrm{Cu}_{2} \mathrm{O}$ and an outer $\mathrm{CuO} / \mathrm{Cu}(\mathrm{OH})_{2}-\mathrm{CuCO}{ }_{3}$ complex layer. The relative amount of material related to these layers depends on $\mathrm{pH}$, potential and anodization time. Cathodic processes comprise the electroreduction of the anodic layer and the electrodeposition of soluble Cu(II) species.

(ii) Solution stirring hinders the formation of the anodic layer and increases the yielding of soluble $\mathrm{Cu}(\mathrm{II})$ species.

(iii) The appearance of soluble species can be explained through a complexation of $\mathrm{Cu}(\mathrm{II})$ at the anodic layer by $\mathrm{HCO}_{3}^{-}$ions.

(iv) The anodic current transients related to the electroformation of the anodic layer and to $\mathrm{Cu}$ electrodissolution can be reproduced by using a model for the nucleation and growth of new phases under diffusion control. The cathodic current transients related to the first electroreduction stage of the anodic layer can be mainly described in terms of a nucleation and growth model under activation control. 
(v) In $\mathrm{NaHCO}_{3}+\mathrm{Na}_{2} \mathrm{CO}_{3}$ solutions the passivity of $\mathrm{Cu}$ is less effective than in either phosphate, borate or plain $\mathrm{NaOH}$ solutions.

Acknowledgement-Financial support for this work by the Gobierno de Canarias (Dirección General de Universidades e Investigación) under contract No. $46 / 01.06 .88$, is gratefully acknowledged.

\section{REFERENCES}

1. U. Bertocci and D. Turner, in Encyclopedia of Electrochemistry of the Elements (Edited by A. J. Bard), Vol. 2. Marcel Dekker, New York (1974).

2. J. van Muylder, in Comprehensive Treatise of Electrochemistry (Edited by J. O'M. Bockris, B. E. Conway, E. Yeager and R. White), Vol. 4, p. 23. Plenum Press, New York (1981).

3. D. W. Shoesmith, T, E. Rummery, D. Owen and W. Lee, J. electrochem. Soc. 123, 790 (1976).

4. W. Ashworth and D. Fairhust, J. electrochem. Soc. 123, 506 (1977).

5. H. H. Strehblow and H. D. Speckmann, Werkstoffe Korros. 35, 512 (1984).

6. M. R. G. de Chialvo, S. L. Marchiano and A. J. Arvia, J. appl. Electrochem. 14, 165 (1984).

7. H. D. Speckmann, M. M. Lohrengel, J. W. Schultze and H. H. Strehblow, Ber. Bunsenges. Phys. Chem. 89, 392 (1985).

8. M. R. G. de Chialyo, R. C. Salvarezza, D. V. Vásquez Moll and A. J. Arvia, Electrochim. Acta 30, 1501 (1985).

9. J. Gómez Becerra, R. C. Salvarezza and A. J. Arvia, Electrochim. Acta 33, 613 (1988).

10. S. Dong, Y. Xie and G. Cheng, Electrochim. Acta 37, 17 (1992).

11. M. R. G. de Chialvo, J. O. Zerbino, S. L. Marchiano and A. J. Arvia, J. appl. Electrochem. 16, 517 (1986).

12. M. Wanner, H. Wiese and K. G. Weil, Ber. Bunsenges. Phys. Chem. 92, 736 (1988).

13. M. Pérez Sánchez, M. Barrera, S. González, R. M. Souto, R. C. Salvarezza and A. J. Arvia, Electrochim. Acta 35, 1337 (1990).

14. C. I. Elsner, R. C. Salvarezza and A. J. Arvia, Electrochim. Acta 33, 1735 (1988).
15. M. M. Laz, R. M. Souto, S. González, R. C. Salvarezza and A. J. Arvia, Electrochim. Acta 37, 655 (1992).

16. D. Yásquez Moll, M. R. G. de Chialvo, R. C. Salvarezza and A. J. Arvia, Electrochim. Acta 30, 1011 (1985).

17. M. G. Figueroa, M. F. L. de Mele, R. C. Salvarezza and A. J. Arvia, Electrochim. Acta 32, 231 (1987).

18. M. R. G. de Chialvo, M. F. L. de Mele, R. C. Salvarezza and A. J. Arvia, Corros. Sci. 28, 121 (1988).

19. R. M. Souto, M. Pérez Sánchez, M. Barrera, S. González, R. C. Salvarezza and A. J. Arvia, Electrochim. Acta 37, 1437 (1992).

20. M. Drogowska, R. L. Brossard and H. Ménard, 42nd. Meeting of the International Society of Electrochemistry, Montreux, 25-30 August, 1991, paper 4-15, J. electrochem. Soc. 139, 39 (1992).

21. D. Dickertmann, F. D. Koppitz and J. W. Schultze, Electrochim. Acta 21, 967 (1976).

22. B. D. Cahan and H. M. Villullas, J. electroanal. Chem. 307, 263 (1991).

23. A. M. Castro Luna, S. L. Marchiano and A. J. Arvia, $J$. appl. Electrochem. 8, 121 (1978).

24. S. L. Marchiano, C. I. Elsner and A. J. Arvia, J. appl. Electrochem. 10, 365 (1980).

25. S. T. Mayer and R. H. Muller, J. electrochem. Soc. 139, 426 (1992).

26. R. M. Smith, A. E. Martell, Critical Stability Constants Vol. 4. Pergamon Press, New York (1976).

27. J. W. Mellor, A Comprehensive Treatise on Inorganic and Theoretical Chemistry, Vol. 3, p. 276. Longmans, Green, London (1928).

27. R. C. Salvarezza, D. V. Vásquez Moll and A. J. Arvia, Electrochim. Acta 32, 1421 (1987).

28. R. C. Salvarezza, D. V. Vásquez Moll and A. J. Arvia, Electrochim. Acta 32, 1421 (1987).

29. D. V. Vásquez Moll, R. C. Salvarezza, H. Videla and A. J. Arvia, J. electrochem. Soc. 132, 754 (1985).

30. W. Davison and J. A. Harrison, J. electroanal. Chem. 44, $213(1973)$

31. R. G. Barradas and E. Bosco, J. electroanal. Chem. 193, 23 (1985)

32. M. E. Garmanov, S. G. Prutchenko, A. S. Sadovskii and V. A. Makarov, Elektrokhimiya 24, 1035 (1988).

33. M. Fleischmann and H. R. Thirsk, in Advances in Electrochemistry and Electrochemical Engineering (Edited by P. Delahay), Vol. 3, p. 123. Interscience, New York (1961). 